INTERNAL PARASITES OF THE SEBAGO SALMON

From BULLETIN OF THE BUREAU OF FISHERIES, Volume XXVII, IgOS

Proceedings of the Fourth International Fishery Congress : Washington, 1008

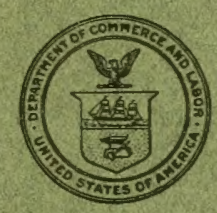

WASHINGTON : : : : : : GOVERNMIENT PRINTING OFFICE $:: \quad: \quad: \quad: \quad: 1910$ 


$$
\gamma
$$


, 





\section{INTERNAL PARASITES OF THE SEBAGO SALMON}

From BULLETIN OF THE BUREAU OF FISHERIES, Volume XXVIII, I 908

Proceedings of the Fourth International Fishery Congress : : Washington, Igo8

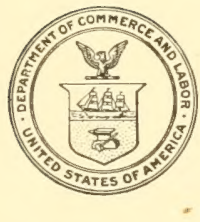

WASHINGTON : : : : : : GOVERNMENT PRINTING OFFICE $:: \quad: \quad: \quad: 1910$ 


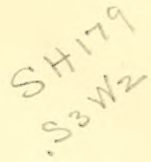

BUREAU OF FISHERIES DOCUMENT NO. 713

Issued April, 1910

APR 301910

Co 8 \& 


\section{INTERNAL PARASITES OF THE SEBAGO SALMON *}

By Henry B. Ward, Ph. D.

Professor of Zoology, University of Illinois

$*$

Paper presented before the Fourth International Fishery Congress held at Washington, U. S. A., September 22 to 26, 1908 
CONTENTS.

*

Historical strvey _...

Parasites of Atlantic salmon, with tabulated summary . . . $\ldots \ldots \ldots \ldots \ldots$

Parasites of Pacific salmon ...

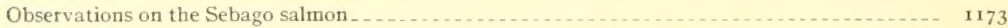

Specific relationships... . . . . .

Source of parasites _ _ _

A new trematode parasite $\ldots \ldots \ldots$

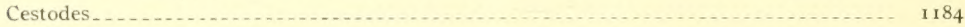

Proteocephalus pusillus, nov. sp

Sparganum sebago, nov. $\mathrm{sp} \ldots \ldots \ldots \ldots$

Nematodes _ _ _.

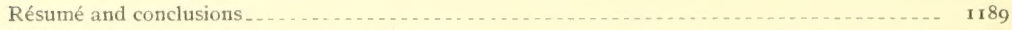

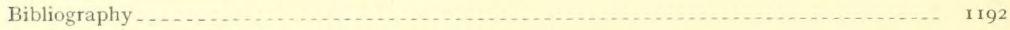

Explanation of plate 


\title{
INTERNAL PARASITES OF THE SEBAGO SALMON.
}

\author{
$*$ \\ BY HENRY B. WARD, Ph. D., \\ Professor of Zoology, University of Illinois.
}

In connection with other investigations of the United States Bureau of Fisheries in Alaska in 1906, I had the privilege of spending two months in study of the parasites of the Pacific salmon. The following year, for comparison of the interesting results of this work with similar studies of Atlantic salmon, I was designated to join a party engaged in a biological survey of $\mathrm{I}_{\text {ake }}$ Sebago, Maine. During six weeks in this region I examined for parasites a number of the Sebago salmon and secured a series of parasites from other fish in the lake and adjacent waters.

The large amount of valuable material obtained on these two trips has engaged my entire attention during the interval since it was secured, and even yet some questions have not been satisfactorily answered. It forms a most interesting contribution to the parasitic fauna of these important fishes and at the same time throws some light on the general relations between an animal and its parasites, which I hope may be of interest to the scientist and of value to the practical fish culturist. This report falls naturally into three partsfirst, a historical summary, which concerns chiefly the European or Atlantic salmon, since this species is the only one that has been studied previous to the present date; second, a report on the findings in the case of the Sebago salmon, which is very closely related to the European species, together with a discussion of the conclusions which may be drawn from these data; and third, a similar report on the Pacific salmon, which is less closely related and rather widely removed geographically from the other two forms. In the present paper are included only the first and second sections of the entire report.

HISTORICAL SURVEY.

PARASITES OF ATLANTIC SALMON.

Rudolphi says that in 1726 Frisch observed a salmon parasite, later known as Bothriocephalus solidus, and in 7335 published some record of its occurrence in a paper entitled "De tæniis in pisiculo aculeato, qui in Marchia Brandenburgia vocatur "Stecherling., "' This is the first account of a salmon parasite to which I have found any reference, and I have been unable to ascertain more precisely the data in this case or to verify the reference. 
The oldest record of a salmon parasite that I have been able to verify is found in a praper by Sporing (175.3), in which he defends the thesis that inhabitants of fluviatile regions are more annoyed by tapeworms than those of other places, no doubt because of the use of half-raw fish. Of weight for his argument is the list of half a dozen fish, including Salmo salar, in which, according to his observations, tapeworm ${ }^{a}$ larvæ are present. The view that man was indebted to the salmon for infection with fish tapeworms was generally current in early times and, though supported by no scientific evidence, persisted until finally thoroughly disproved by Zschokke (1890). Now it may be regarded as fully established that man does not acquire a single parasite in any way by the use of salmon as food.

O. F. Müller $(1776,1777,1780$ ) was the first to describe and name according to scientific principles some of the parasites from Salmo salar. He named Fasciola varica, afterwards called Distoma varicum by Zeder; Echinorhynchus salmonis, changed to E. inflatus by Rudolphi; E. lavis, later changed to E. nodulosus; Tania solida, which later became Bothriocephalus solidus Rudolphi, and Tania salmonis, later called $B$. proboscideus Rudolphi.

Goeze (1782) gave the first description of Echinorhynchus quadrirostris, later more correctly diagnosed and named Tetrarhynchus appendiculatus by Rudolphi (r8og). Goeze also gave a good description of the encapsulated nematode larva common in salmon, which he referred to Cucullanus, though doubtfully. Rudolphi afterwards named this form Ascaris capsularia.

The first formal list of parasites from Salmo salar is that given by Rudolphi in 1810 , who lists as parasites already recorded for this host eight ${ }^{b}$ species, as follows:

Bothriocephalus proboscideus.

Bothriocephalus solidus.

Tetrarhynchus appendiculatus.

Distoma varicum.

Ascaris capsularia.

Dub. (?Cucullanus).

Echinorhynchus inflatus.

Echinorhynchus (?) nodulosus.

It is of interest to note that Rudolphi records opposite every one of these named from six to eight earlier references to the particular species. Five of them were originally observed by O. F. Müller, two by Goeze, and one is a doubtful species.

a Braun (1894), who cites the case, says Ligula larvæ, but as this genus has not been recorded for Salmo salar I take it to apply only to certain of the host species listed. The original author of course did not distinguish even genera in his observations.

${ }^{b}$ In the appendix (vol. II, part 2, p. 376) Rudolphi lists another find under the name of Distoma crenatum. This material was examined by Lühe (I9OI, 40I) and pronounced not a hemiurid, but fur. ther determination could not be made. 
In a later paper (I8I9) Rudolphi added to the list no new parasite, Distoma appendiculatum Rudolphi being merely another name for $D$. crenatum of the appendix in the earlier work. In this list Echinorhynchus fusiformis Zeder is only a change of name from $E$. inflatus of the earlier list; $E$. nodulosus is omitted; Bothriocephalus solidus is interpreted as introduced by accident when its proper hosts chance to be eaten by the salmon. 'Thus the true list of salmon parasites is actually reduced, and numbers only seven in this later list of Rudolphi.

In I 851 , Diesing in his "Systema Helminthum" recorded for Salmo salar ten parasites, as follows:

Distomum varicum.

Stenobothrium appendiculatum.

Schistocephalus dimorphus.

Dibothrium proboscideum.

Ëchinorhynchus pachysomus.

Echinorhynchus proteus.

Agamonema capsularia.

Ascaris capsularia.

Ascaris clavata.

Cucullanus elegans.

Although one notes at once the unfamiliar appearance of the list due to numerous changes in the names employed, yet only the last two are actually new forms. Thus, in spite of the frequent attention given to the salmon, the list of its parasites had only increased from five to ten species in the seventyfive years since O. F. Müller first made scientific records of its parasitic fauna in Denmark.

In 1878 von Linstow in the "Compendium der Helminthologie" listed 16 parasites for Salmo salar. New are:

Distomum ocreatum Rudolphi.

Distomum reflexum Creplin.

Bothriocephalus cordiceps Leidy. ${ }^{a}$

Tetrarhynchus grossus Rudolphi.

Tetrarhynchus solidus Drummond.

In his "Nachtrag" (ז889) the same author includes five new species of parasites recorded for Salmo salar since the appearance of the earlier record, namely:

Agamonema communis Diesing.

Distomum miescheri Zschokke.

Bothriocephalus sp.? Zschokke.

Leuckartia sp.? Moniez. ${ }^{b}$

Tetrabothrium minimum von Linstow.

a As indicated in the discussion (p. I 166), this is an error in citation.

$b$ Moniez ( $188 \mathrm{I}$ ) found three cestodes in the pyloric cœea of a salmon obtained in the fish market at Lille (France), on which he based a new genus, Leuckartia. Except for the lack of a scolex, the specimens agree well with Bothriocephalus infundibuliformis, better Abothrium crassum, to which they may well belong. 
Without tracing in detail the further progress of the record, it may be said that at the present date the list includes 47 species, which are enumerated later in this paper. It is of importance for a consideration of the distribution of the salmon parasites, the especial object of this paper, to review the later studies in this field in their geographic arrangement in order to compare elearly the parasites found in one area with those which are present in another. The salmon which have been most intensively studied are those of the Rhine.

Our knowledge of these forms is due largely to a series of papers by the distinguished Swiss helminthologist, Fir. 7,schokke, of Basel, which cover the work of many years. The first record of Zschokke (IS89) included examinations of 45 fish, of which +2 were found infected with parasites. All the fish were caught in the Rhine in November, December, and January, and the following parasitic species were listed:

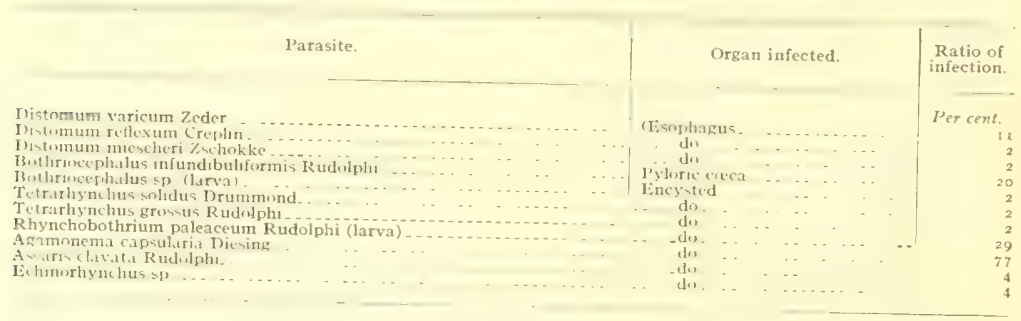

Not a single parasite lay in the alimentary canal below the pyloric coeca. Monticelli notes that most sharks lose their parasites after a long stay in an aquarium, and Zschokke has observed that marine fish otherwise heavily infested lose their intestinal parasites very rapilly when subjected to fasting in captivity. The Rhine salmon behaves with regard to parasites just like a fasting sea fish. Its parasitic fauna manifests an almost purely marine aspect. I'resh-water elements are scanty and insignificant. Clearly, then, the Rhine salmon takes little or no food during its fresh-water migration. Data on individual species close the paper.

The parasitic fauna of the Atlantic salmon was discussed in extended fashion later by Zschokke ( 1891 ) on the basis of his own previous studies and those of earlier authors. In all he had examinerl the viscera of I 29 fish caught in the Rhine. The almentary canal contained in all cases the thick yellowish or yellow-brown mucus, but never any recognizable remnants of food materials, although once plant fibers and undigested remains of a Gammanus pulcx were found. As in similar previously reported cases, so here also the occurrence of these fragments should be regarded as purely accidental. 
Only four of the I29 salmon examined were free from parasites, and in all 20 species of the latter were recorded from the infested fish. The list of parasites recorded is as follows:

Ascaris adunca Rudolphi.

Ascaris angulata Rudolphi.

Ascaris clavata Rudolphi.

Ascaris (Agamonema) capsularia Diesing.

Ascaris (Agamonema) communis Diesing.

Echinorhynchus acus Rudolphi.

Echinorhynchus agilis Rudolphi.

Echinorhynchus proteus Westrumb.

Distomum varicum $Z$ eder.

Distomum reflexum Creplin.

Distomum miescheri Zschokke.

Schistocephalus dimorphus Creplin.

Bothriocephalus infundibuliformis Rudolphi.

Bothriocephalus osmeri (larva) von Linstow.

Bothriocephalus sp. I (larva). ${ }^{a}$

Bothriocephalus sp. II (larva).

Rhynchobothrium paleaceum (larva) Rudolphi.

Tetrarhynchus solidus Drummond.

Tetrarhynchus grossus Rudolphi.

Tetrarhynchus macrobothrius von Siebold (= Stenobothrium appendiculatum Diesing).

Five of these species (Ascaris capsularia, Distomum varicum, Bothriocephalus infundibuliformis, Rhynchobothrium paleaceum, and Tetrarhynchus macrobothrius) are abundant, almost regular in their occurrence, while the other forms are relatively rare in the Rhine salmon. The common parasites were also usually abundant in the individual host; thus 20 to 40 specimens of Ascaris capsularia were often found in a single host. Of Distomum varicum, from 30 to 50 individuals were taken from the œsophagus of one fish. In some cases Bothriocephalus infundibuliformis was present in large numbers, but usually in one or a few weak, starved specimens. Rhynchobothrium paleaceum and Tetrarhynchus macrobothrius occurred in from 20 to 25 individuals in a single host. All other parasites were found in small numbers, often only a single specimen of any one species.

Among the I29 Rhine salmon investigated + were free from parasites, 55 sheltered a single species of parasite, and 43 but two species, while 20 had three species, 6 had four species, and I had five species of parasites.

a The various bothriocephalid larvæ which occur in the salmon are discussed in a separate paper by Zschokke (1890). On the basis of morphologic data he inclined in this paper to the view that five different forms, indicating as many species, might be distinguished. Later studies showed the first to belong to Bothriocephalus osmerivon Linstow. This is the form he listed at first (x889) as Bothriocephalus sp. The second is sp. I of the table, the third and fourth are united as sp. II of the table, und the fifth becomes sp. III of the table (see p. 1168). 
In not a single case was a parasite found in the alimentary canal below the pyloric coeca. Indeed, parasites which in other hosts inhabit only the intestine, were found in the Rhine salmon to infest stomach and oesophagus, as if better protected there than in the vicinity of the anus. The Rhine salmon loses its intestinal guests like any fasting fish, and through the exclusion of food any new importation of worms is prevented. From the absence of parasites behind the pyloric coeca one may conclude indirectly that Salmo salar really fasts in the Rhine. When this species enters the river it is richly laden with parasites. It loses its intestinal guests and these are not replaced by any new supply. There remain only the natural inhabitants of the anterior regions of the canal and those which can withdraw thither. Even these protected species diminish in number of species and individuals as the salmon remains longer in fresh water and climbs higher in the stream, until finally there are left only encapsulated forms. The journey up the Rhine has proved at the same time a means of eliminating the intestinal parasites. Some investigators, although without knowledge of these facts, have yet endeavored to explain the migration of many fish as due to the necessity of freeing themselves from parasites acquired in the ocean.

Salmon caught in Holland, in the lower reaches of the Rhine, are richly infested with parasites. Several species were regularly found in large numbers and the parasitic fauna recalls strikingly that of the ocean salmon. Distomum varicum was very abundant in the csophagus and Bothriocephalus infundibuliformis in the pyloric coeca. But fish from the upper reaches of the Rhine presented a radically different picture. The parasites in oesophagus and stomach were very rare. Distomum varicum had disappeared and Bothriocephalus infundibuliformis appeared only as single, weak, emaciated specimens. Often the entire alimentary tract yielded no trace of a parasite.

The parasitic fauna of the Rhine salmon decreases in proportion as the fish ascends the stream.

A study of the seasonal distribution of parasites in the Rhine salmon evidences that the number of species present becomes reduced in the winter months, and the number of individuals also falls off markedly. The minimum is reached in November and December, the months of spawning, when the fish has penetrated farthest upstream. It has lost its unbidden guests on the long journey. The maximum of parasitic infection is found in the summer months, May to July, when the schools of salmon enter the river. Naturally the journey exerts no influence upon those parasites which inhabit closed organs.

The question next considered is the origin of the salmon's parasites, whether marine, limnetic, or indifferent in character. The analysis of the forms recorded indicates that the Rhine salmon does not exhibit a single true limnetic parasite, 
and its most abundant guests are typically marine. In spite of a long and repeated sojourn in the river it does not infect itself with a single fresh-water parasite, a fact that indicates strongly the complete fasting of the salmon while in the Rhine. In other migratory fish the marine elements become greatly reduced or even disappear entirely. Yet tabular comparisons show that in contrast with the Rhine salmon all other migratory fish infect themselves in fresh water more or less strongly with parasites, thus indicating that whereas the salmon fasts in the Rhine, its near relatives feed abundantly on wandering from the ocean into the river.

It was possible to examine also 34 salmon from the Baltic Sea; all of them were infected, and a total of 12 species of parasites were recorded from them, as follows:
Ascaris adunca Rudolphi.
Ascaris (Agamonema) capsularis Diesing.
Ascaris (Agamonema) communis Diesing.
Ascaris aculeati von Linstow.
Ëchinorhynchus acus Rudolphi.
Echinorhynchus pachysomus Creplin.
Distomum varicum Zeder.
Distomum appendiculatum Rudolphi.
Bothriocephalus infundibuliformis Rudolphi.
Bothriocephalus sp. Ir (larva).
Bothriocephalus sp. III (larva).
T'riænophorus nodulosus Rudolphi (larva).

The Baltic salmon is much more heavily parasitized than the salmon of the Rhine. Seven parasites are common to both, and of these five are more abundant in the Baltic salmon and two only more abundant in the Rhine salmon, while six parasites of the former do not occur in the latter. The relative infestation of the two forms is shown in the accompanying synopsis:

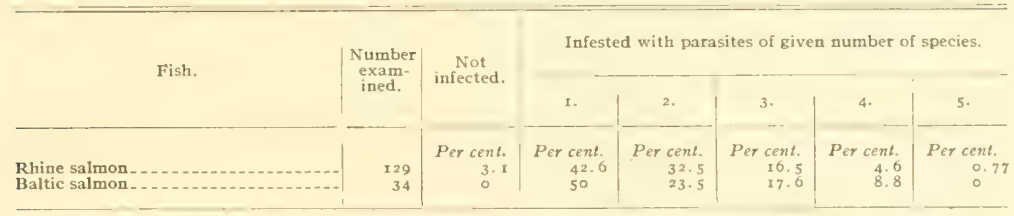

Of parasitic species found in the Baltic salmon, Bothriocephalus infundibuliformis was present often in enormous numbers, and the same was true of Distomum varicum. On the other hand Ascaris capsularis did not manifest the frequence or the abundance already noted for the Rhine salmon. Everything indicates a rich and uninterrupted consumption of food by the Baltic 
type in contrast with the fasting Rhine fish. ${ }^{a}$ Parasites are also found in the intestine behind the pylorus, where the Rhine salmon remains free from parasites. Among the intestinal parasites of the Baltic salmon also are included no true limnetic species. Such only lie encapsulated in various organs. 'This indicates that the infection with the true fresh-water parasites, Cucullanus, Trianophorus, Ascaris aculeati, actually occurs in the rivers. The Baltic salmon comes into fresh water as richly laden with parasites as the fish caught in the lower stretches of the Rhine in Holland. While the parasitic fauma of the Rhine salmon decreases in proportion as it ascends the stream, that of the salmon in many other rivers is enriched by numerous limnetic elements. The natural explanation lies in the fasting of the Rhine salmon, whereas its relatives in other streams do not cease taking food. The Baltic salmon, having returned to the ocean, loses the limnetic parasites of the open intestine but retains those located in the closed organs of the host.

The material is too scanty to determine a seasonal distribution, if any exists, and in fact the food of the Baltic salmon undergoes little change throughout the entire year, so that no general modification would be expected in the parasitic fauna, variations being merely of an individual or casual type.

Upon a careful study of the individual species the parasitic fauna of the Baltic salmon manifests a more varied aspect than that of its relative. There are 2 pure marine forms, in contrast to 8 in the Rhine salmon, 2 pure limnetic species as against not a single one in the other host, 6 parasites found in both marine and fresh-water fishes, and 3 parasites found only in the Baltic salmon, with a fourth which can not be assigned with certainty to either type of environment. It is very striking that the purely marine Tetrarhynchi so abundant in the Rhine salmon have not yet been demonstrated in the Baltic fish. These relations are indicated in the appended table of parasites from the European salmon, collated from various authors.

The Rhine salmon shelters a purely marine parasitic fauna, while the Baltic salmon reckons many limnetic forms among its parasitic guests. This remarkable condition finds its explanation in the continued feeding of the latter type,

a One should not forget in estimating this factor as presented by Zschokke that in one important respect conditions are not identical. The Baltic salmon are still in salt water; not until they enter some estuary and begin the ascent of some river do they meet the fresh water environment to which the Rhine salmon investigated by Zschokke are subject. To secure an exact parallel one should compare the Baltic salmon with such of the Rhine variety as may be captured in the North Sea. Zschokke refers in a later paper to some taken from this body of water and notes in their case also that the average degree of infection with parasites is greater than in the case of those fish taken from the Rhine stream itself. This fact only emphasizes the immediateness and definiteness of the effect on the parasitic fauna of the salmon which is produced by the fresh water environment and abstinence from food. 
even in fresh water, and the resulting enrichment of its parasitic fauna with limnetic forms when it returns to the sea.

The parasitic record reflects clearly the manner of life led by any host.

In all, 33 species have been recorded from this salmon, making the list of its parasites one of the longest known for any fish. The list of these is then given, as follows:

Ascaris adunca Rudolphi.

Ascaris angulata Rudolphi.

Ascaris clavata Rudolphi.

Ascaris (Agamonema) capsularis Diesing.

Ascaris (Agamonema) communis Diesing.

Ascaris aculeati von Linstow.

Cucullanus elegans Zeder.

Echinorhynchus proteus Westrumb.

Echinorhynchus pachysomus Creplin.

Echinorhynchus acus Rudolphi.

Echinorhynchus agilis Rudolphi.

Distomum varicum $Z$ eder.

Distomum reflexum Creplin.

Distomum miescheri Zschokke.

Distomum appendiculatum Rudolphi.

Distomum ocreatum Rudolphi.

Distomum tereticolle Rudolphi.

Distomum sp. McIntosh.

Bothriocephalus infundibuliformis Rudolphi.

Bothriocephalus cordiceps Leidy.

Bothriocephalus osmeri (larva) von Linstow.

Bothriocephalus sp. I (larva) Zscholke.

Bothriocephalus sp. II (larva) Zschokke.

Bothriocephalus sp. III (larva) Zschokke.

Schistocephalus dimorphus Creplin.

Triænophorus nodulosus (larva) Rudolphi.

Leuckartia sp. Moniez.

Tetrabothrium minimum von Linstow.

Rhynchobothrium paleaceum Rudolphi.

Tetrarhynchus solidus.

Tetrarhynchus grossus Rudolphi.

Tetrarhynchus macrobothrius von Siebold (= Stenobothrium appendiculatum Diesing).

Tetrarhynchus sp. McIntosh.

The paper of Zschokke closes with a detailed discussion of the biology and relationships of the individual salmon parasites, including citations of the work of previous investigators on these forms. 
In a later paper Zschokte (I896) lists the parasites of salmon caught in the Rhine at Basel, including the results of examinations extending over several years and embracing 16 species, as follows:

Bothriocephalus infundibuliformis Diesing.

Tetrarhynchus solidus Drummond.

Tetrarhynchus sp.

Schistocephalus dimorphus.

Distomum varicum Zeder.

Distomum appendiculatum Rudolphi.

Distomum ocreatum Rudolphi.

Distomum reflexum Creplin.

Distomum miescheri Zschokke.

Ascaris clavata Rudolphi.

Ascaris capsularia Diesing.

Ascaris sp.

Ascaris sp.

Echinorhynchus clavæceps Zeder.

Echinorhynchus acus Rudolphi.

Pisicola geometra Linnæus.

Unreported previously are Echinorhynchus clavaceps Zeder, Pisicola geometra Linnxus, and possibly also two undetermined species of Ascaris. Eliminating forms which do not properly belong to the Rhine at Basel and adding species recorded previously, the net result is I 7 species of parasites in the salmon at Basel, or one-third of the total known parasitic fauna of that region. Of these $I_{7}, I_{3}$ are characteristic of the salmon and wanting in other fish there. The large majority of the list are of purely marine character and a further group is characteristic of migratory fish, leaving nothing of a limnetic type save Pisicola geometra, a leech which is merely a temporary ectoparasite.

This paper records also the results of the examination of additional salmon from the North Sea, the lower Rhine, and the middle and upper Rhine, making the grand total of $\mathrm{x} 79$ Rhine salmon examined by this author. The only new parasite recorded is Scolex polymorphus Rudolphi. Again, later, Zschokke (1902, p. I 28-130) discusses the records of his earlier work without adding any new data.

In studies on the Rhine salmon Hoek (I 899) records that he found in the young fish an ascarid, according to Fritsch -1 . clacata, and repeatedly specimens of a species of Echinorhynchus which Fritsch names E. pachysomus Creplin, though he did not observe it in the young salmon. In Hoek's opinion the forms obtained, though not fully grown, agree better with the description of E. proteus Westrumb, and indeed with the more limited concept of the name according to Hammann. Hoek observed not infrequently that young salmon were infested with a leech, Cystobranchus (Pisicola) respirans Troesch, which lived as an ectoparasite on the skin. 
Concerning the Baltic salmon, other fragmentary data are also on record. Olsson (1867) reported Bothriocephalus proboscideus Rudolphi as frequent in Salmo salar both from fresh and from salt water during April and August. Later the same author (Olsson, 18,6) listed Distomum appondiculatum Rudolphi as frequent in Salmo salar during August. Again (1893) he reported Distoma appendiculatum Rudolphi from the stomach as ahundant in July. The material came from the Baltic Sea and the Gulf of Bothnia.

Hausmann (1897) lists from Salmo salar Distomum appendiculatum, D. ocreatum, $D$. reflexum, and $D$. varicum. Among 20 specimens examined 13 only were infested with trematodes.

Mühling ( 1898 ) records from Salmo salar in East Prussia six species of parasites, as follows: Bothriotania proboscidea, Apoblema appendiculatum, Echinorhynchus acus, Ech. fusiformis, Ech. proteus, and Ech. pachysomus. The first two are very common, the others occasional. Ech. fusiformis is cited after Neumann.

G. Schneider (1902) reports the following data concerning salmon parasites in Finland: A salmon I m. long, caught November 6, I900, in the mouth of the river, was infested with several hundred individuals of Bothriotonia proboscidea Batsch, which entirely filled the pylorus portion of the intestine and of the pyloric coeca. Otherwise the intestine contained no parasites and no food. A second salmon, investigated fresh July 2, I902, had in the intestine the young and adult Bothriotemia proboscidca Batsch and one Echinorhynchus larva, which, however, evidently came from fish that had been eaten. In the stomach of this salmon he found Clupea sprattus Linnæus [p. Is the name is given as ( $/ u p e a$ harengus membras L.] and in the intestine remains of digested fishes, probably also herring. The synchronus presence of herring remains and of very young Bethriotonia in the intestine of this salmon confirms fully his formerly expressed opinion that the salmon infects itself with tapeworms through eating the herring.

According to Schneider (1902, p. 20), Kessler in a Russian paper 1eported the occurrence of adult Bothriotania proboscidea in the intestine of Salmo salar from Lake Onega. This body of water is directly connected with the Baltic Sea, where, according to Mühling, as just noted, this species is a very common parasite of the salmon. Schneider has also found it abundant in salmon from the Gulf of Finland.

No doubt some observations have been made on the parasites of salmon in the Scandinavian peninsula, but they have thus far eluded my search.

Concerning the parasites in the British Isles many observations are on record. But they concern individual investigations at particular locations, and as a rule do not cover any continuous study of the problem. In consequence the lists are not as complete as those already cited for the Rhine and the Baltic, 
and it is somewhat difficult to draw a precise comparison with the data for the latter regions. First may be placed such records as concern streams directly connected with the North Sea, and hence with the body of water from which the Rhine salmon come.

Concerning the parasites of salmon in the Tay, McIntosh (I 863) has recorded certain data. More than 100 fish were examined, few were entirely free from parasites, many were richly infested. The parasitic species were both frequent and abundant, although only io species are definitely recorded, as against I 4 in the Baltic and 20 in the Rhine salmon. The species from Tay salmon McIntosh lists as follows:

Ascaris (Agamonema) capsularia Diesing.

Echinorhynchus proteus Westrumb.

Echinorhynchus pachysomus Creplin.

Distomum varicum Creplin.

Distomum tereticolle Rudolphi.

Distomum sp.

Bothriocephalus infundibuliformis Rudolphi.

Tetrabothrium minimum von Linstow.

Tetrarhynchus macrobothrius von Siebold.

Tetrarhynchus sp.

The examination of this list shows clearly that the Scotch salmon combines elements from the parasitic fatma of both its relatives, the Rhine salmon and the Baltic salmon. The strong and continued infestation of the intestine below the pylorus goes to establish the fact that the taking of food is continuous.

No seasonal distribution of parasites could be noted, but the character of the parasitic species was striking. One pure marine species and two almost equally such, together with five characteristic salmonid parasites, show that the major portion of the parasitic fauna is of marine origin. On the other hand, the intestinal parasites were in large part not marine, but limnetic forms or such as are typical in the salmon. As in the Rhine salmon, so also in the Tay, the marine alimentary parasites are gradually lost without being renewed. They are replaced by such as are of evident limnetic character. Hence the conclusion of McIntosh, based on other evidence also, that the Tay salmon does from time to time take nourishment during its stay in fresh water. A comparison of the parasitic fauna of the three salmons gives, according to Zschokke, the following:

\begin{tabular}{|c|c|c|c|c|c|c|c|}
\hline \multirow[b]{2}{*}{ Fish. } & \multirow{2}{*}{$\begin{array}{l}\text { Number of } \\
\text { parasitic } \\
\text { species. }\end{array}$} & \multirow{2}{*}{$\begin{array}{l}\text { Typical } \\
\text { for the } \\
\text { particular } \\
\text { salmon. }\end{array}$} & \multirow{2}{*}{$\begin{array}{l}\text { Found } \\
\text { also in } \\
\text { other } \\
\text { salmon } \\
\text { and other } \\
\text { localities. }\end{array}$} & \multirow{2}{*}{$\begin{array}{l}\text { In other } \\
\text { migratory } \\
\text { fishas weli } \\
\text { as the } \\
\text { salmon. }\end{array}$} & \multicolumn{3}{|c|}{ Besides in migratory fish also in- } \\
\hline & & & & & $\begin{array}{c}\text { Marine } \\
\text { Esll. }\end{array}$ & $\begin{array}{l}\text { Limnetic } \\
\text { fish. }\end{array}$ & $\begin{array}{l}\text { Both ma- } \\
\text { rine and } \\
\text { limnetic. }\end{array}$ \\
\hline
\end{tabular}


Much later than the work just outlined is a paper by Tosh (I905) in which he discusses his work on the internal parasites of the Tweed salmon. The material was collected in I 895 at a single place. The author notes the distinctly marine character of the parasitic fauna of this salmon, attributing it to the fact that "salmon do not feed in the fresh water of a short river like the Tweed, except under extraordinary conditions, when a prolonged stay is imposed upon them." In all he lists i 5 species, as follows:

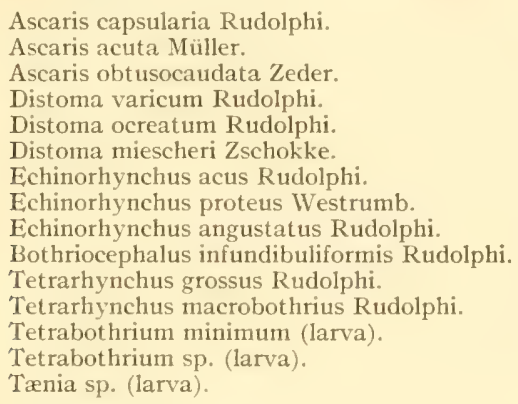

Details are given concerning the frequence, appearance, and biology of each form. The most important is held to be Bothriocephalus infundibuliformis, which, according to an appended table, occurs in 26.4 per cent of the 892 fish examined. It does not seem, in the opinion of 'Tosh, to be seriously harmful to the host and is found in the largest and best-fed fish in numbers ranging from I to 6 per host. The tremendous infestations noted by Zschokke apparently do not occur in this region in the salmon, although observed in the sea trout.

The only notices from Ireland concerning salmon parasites are brief and also of long standing. Drummond ( 1838 ), writing in Belfast, described Tetrarhynchus grossus from the abdominal cavity of the salmon, which he found only once, and Tetrarhynchus solidus, new species, from the peritoneum and mesentery, which he took from three salmon in July, 1838 .

Somewhat later Bellingham ( 1844 ) listed among the entozoa indigenous to Ireland the following taken from the salmon, namely:

Ascaris capsularia, on the peritoneum; also in 14 other species of fish, all marine.

Ascaris clavata, from intestine and peritoneum; also in 9 other species of fish, all marine.

Distoma varicum, from the stomach; common in some localities and seasons, rare in others.

Tetrarhynchus grossus, from the abdominal cavity; entered in this list on the authority of Drummond (1838). 
Tetrarhynchus solidus, from the abdominal cavity; a single specimen loose in peritoneal cavity.

Bothriocephalus proboscideus, from intestine and pyloric coeca; exceedingly common and most so in largest and fattest salmon.

One should always recall the relative value of such comparisons as those in the preceding pages. The fact that from Irish salmon only 6 species of parasites are recorded, from the Scotch form Io species, from the Baltic form it species, and from the Rhine salmon 20 species, is partly accounted for by the amount of attention directed to the various forms. Thus the first record concerning the Rhine salmon (Zschokke, I889) listed i s species of parasites obtainer in the course of examining 45 specimens of the Rhine salmon. The second record by the same author (Zschokke, 189I) included 20 species of parasites from I 29 hosts, and the third record (Zschokke, I896) gave 23 species of parasites from a total of 179 hosts. Of these 136 came from the Rhine itself and 43 from the sea. More extended study of any host will increase the list of the parasites which it is known to support.

The same species of fish, Salmo salar, occurs in streams on the western or American coast of the Atlantic Ocean. Thus far no one appears to have devoted especial attention to the parasitic fauna of the American fish, but some scattered references to species found in our American salmon are recorded by different authors. No doubt the list can be extended considerably by longer search, but so far as I can ascertain the following brief references include all records of salmon parasites made on this continent and published up to the present time.

According to 7,schokke ( $189 \mathrm{I}$ ) I,eidy reported Bothriocephalus cordiceps from the intestine of Trutta salar Linnæus. The reference, which is apparently cited from von Linstow ( 1878 ), is incorrect both in location and content. Leidy (I87I) reported on the authority of Professor Hayden "the brook trout, Salmo fontinalis, of the headwaters of the Yellowstone River, to be much infested with a species of tapeworm *** from the abdominal cavity, but not from the intestinal canal * * *. It belongs to the old genus Bothriocephalus, and to that section now named Dibothrium." This new species was named Dibothrium cordiceps. The species was subsequently studied in detail by Linton. I am unable to find any other reference to this parasite in the writings of Leidy or any record of its occurrence in any other than the original host, which was in reality Salmo mykiss, the Rocky Mountain trout; the adult parasite occurs in the intestine of the American white pelican, Pelecanus erythrorhynchus. This parasite accordingly seems to have no relation whatever to the salmon and should be eliminated from the list of its parasites.

In the catalogue of parasites from various collections in the United States by Stiles and Hassall (IS94) there are listed from Salmo salar Bothriocephalus 
proboscideus from Berlin in the Stiles collection and Bothriocephalus sp. from Fngland in the Hassall collection; no specimens whatever are noted as having been taken from autochthonous fish.

In a list of trematodes from Canadian fishes Stafford (I904) records from Salmo salar Linnæus, Derogenes varicus O. F. Müller, found in mouth, œesophagus, and stomach; Hemiurus appendiculatus Rudolphi, found in oesophagus and stomach; Lecithaster bothryophorus Olsson (=Apoblema mollissimum Levinsen), and Sinistroporus simplex Rudolphi, from the intestine. The fish were apparently purchased in the markets in Montreal and represent conditions during the spring and autumn months of 1903.

I have found no further references to the parasitic fauna of Salmo salar on this continent. The list contains two species not previously recorded for this host, and yet it is insignificant in comparison with European records for the same host.

Appended hereto is a tabular list of all parasites hitherto reported from Salmo salar, arranged according to the place which the parasites hold in the present accepted system. The taxonomy of these groups is at present in such confusion that I have contented myself with entering the names employed by the author cited and in making a few inevitable corrections. Any attempt to adjust the nomenclature adequately would demand an amount of time beyond my present command and an amount of space out of keeping with the rest of this article. By the citation in the table of the authority, date, locality, and location, the reader is enabled to form at a glance a general opinion regarding the importance of any parasite yet reported from the salmon and to follow up its record with the minimum delay. 


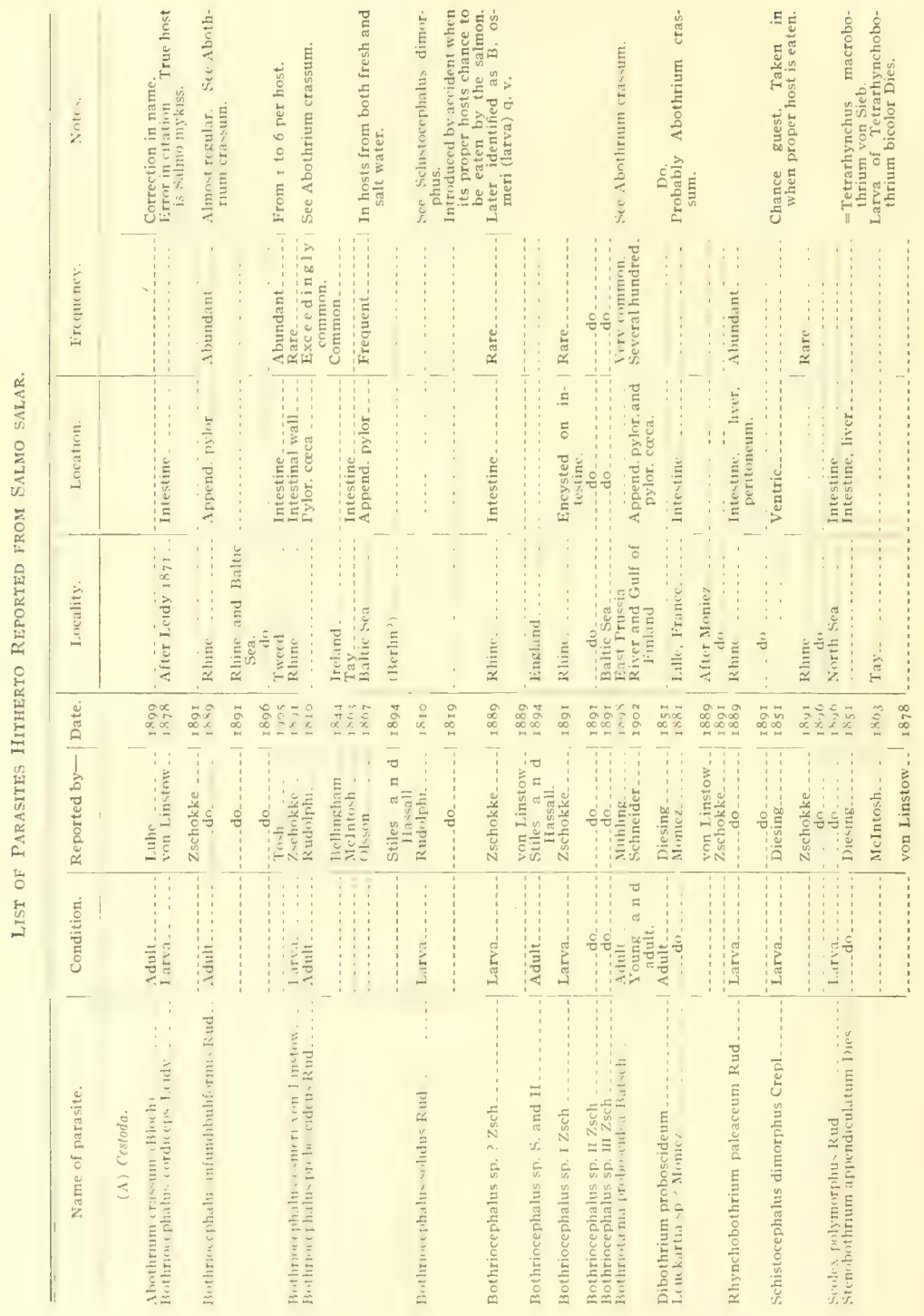


INTERNAL PARASITES OF THE SEBAGO SALMON.

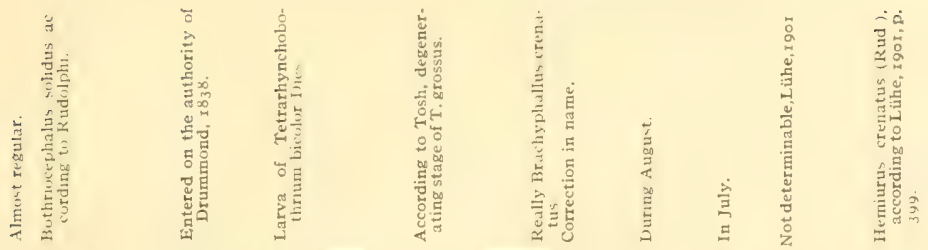

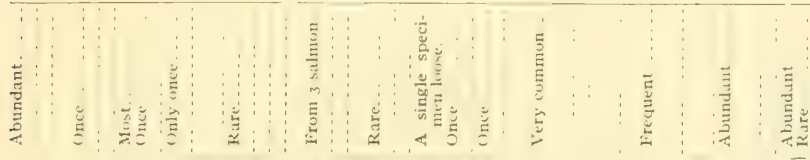
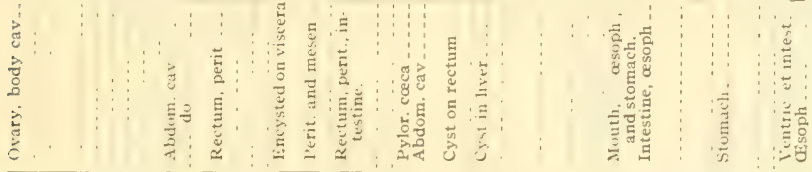

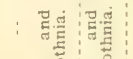

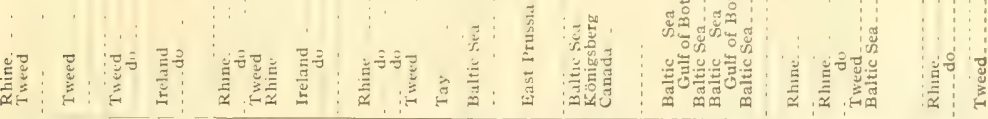

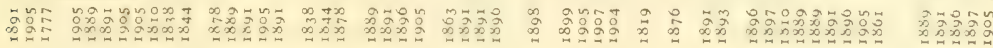

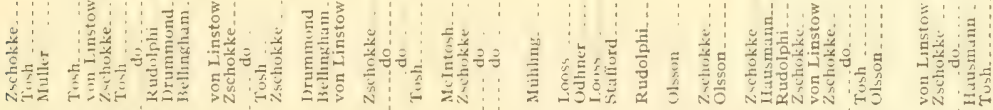

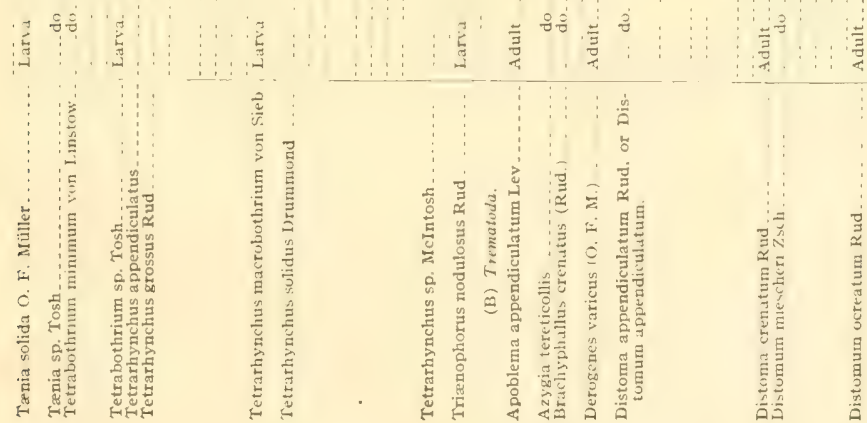




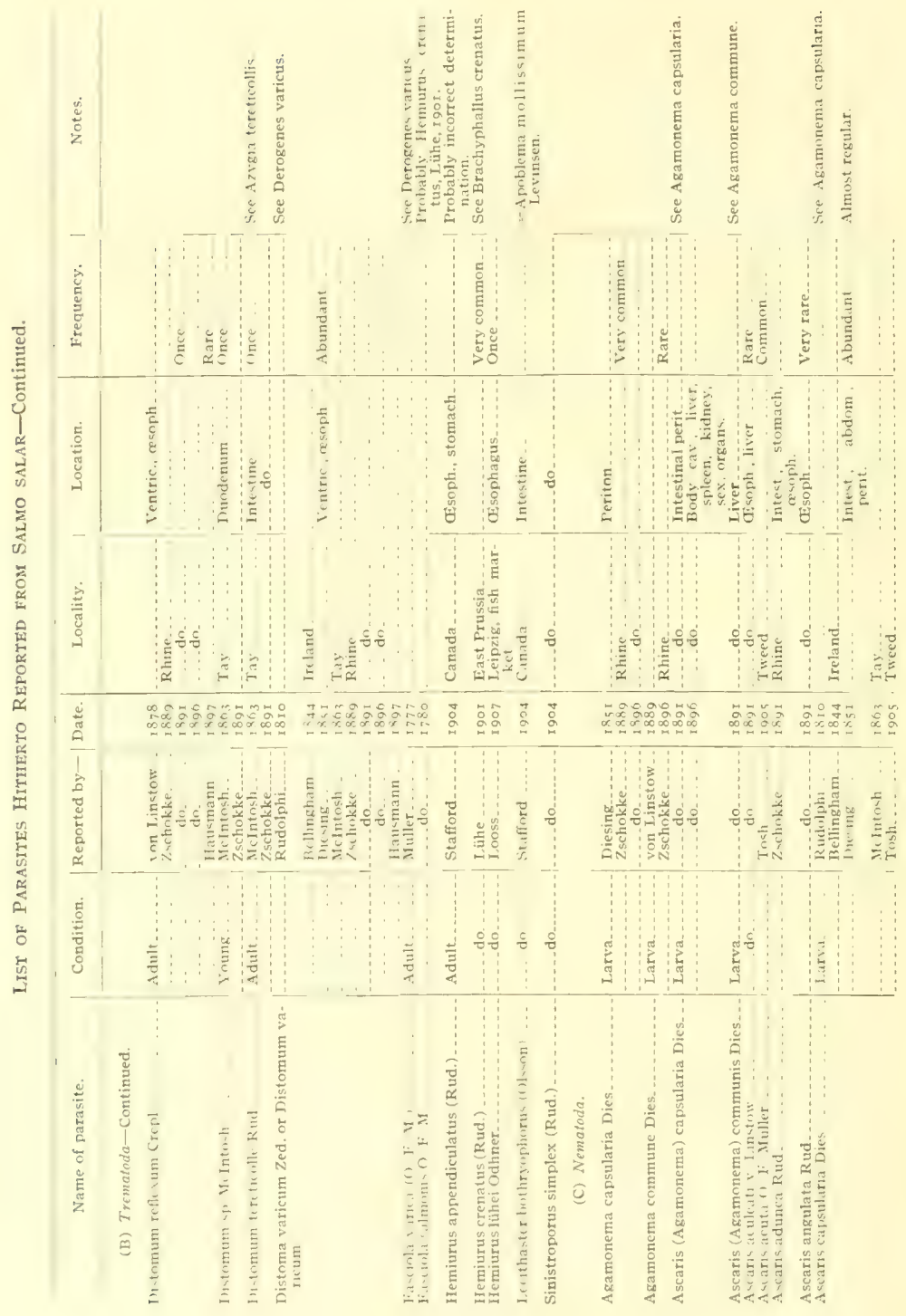


INTERNAL PARASITES OF THE SEBAGO SALMON,

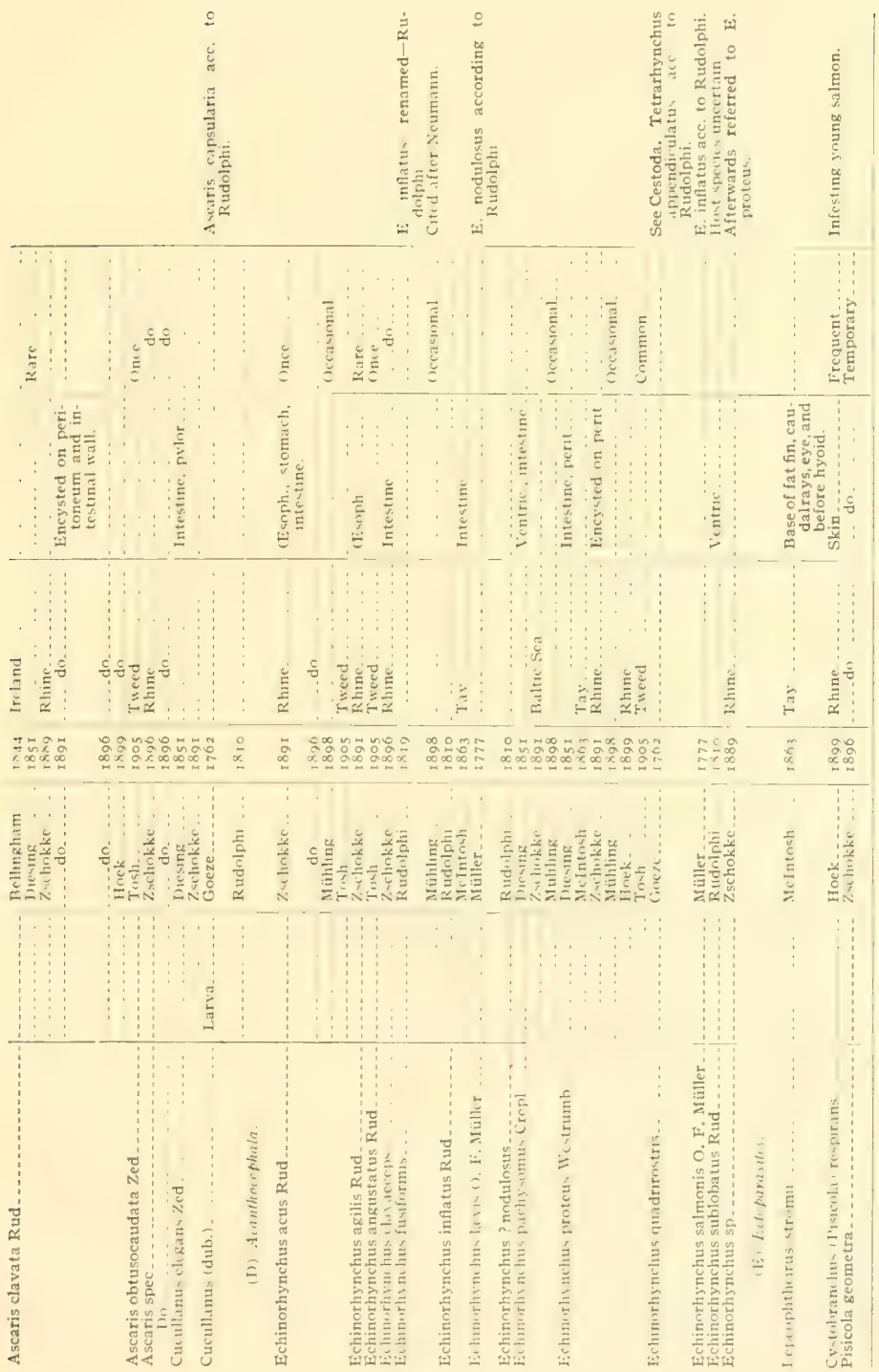


PARASITES OF PACIFIC SALMON.

The list of parasites for Atlantic salmon in America, though small, is much more extended than the records concerning the Pacific salmon. While tremendous numbers of the latter fish, which belong to several species of the genus Oncorhynchus, are taken every year for commercial purposes, apparently no one has studied the parasitic fauna or done more than to record casually a few data taken during a study of some other factor concerning the species. Even of such notes I have found only a very few.

In a report on the life history of the Alaska salmon, Bean (189o, and also I893) noted a few items concerning parasites. He mentions the presence in I 889 of numerous intestinal worms in the red salmon and finds that all species of salmon [in fresh water?] are more or less covered with parasitic copepoda.

Much more extensive are the notes made by the brilliant young naturalist and student of the Pacific salmon, Cloudsley Rutter, who only a short time back met such an untimely death.

In the course of investigations on the natural history of the quinnat salmon in the Sacramento River, Rutter ( 1902 ) records some interesting items regarding their parasites. A common pest in the adult of this species in fresh water is a parasitic copepod which attaches itself to the gill filaments. Usually not numerous on a single fish, they yet sometimes destroy the gill filaments almost entirely. The intestine of the spawning salmon is frequently inhabited by tapeworms extending into the coeca and at times filling them completely. They do not occur in the stomach. In 1898 they were much more abundant than in I900. Among 200 young salmon examined from fresh-water stations in the Sacramento basin in May, 1898 , and April, 1899, parasites were found in the stomach contents of $3 \mathrm{I}$ fish. They were described as of two or three kinds, one elongated [cestode?], the others short and grain-like [trematodes?]. Rutter thinks that residence in fresh water is conducive to the growth of parasites in the stomachs of young salmon. He gives the following tables of their occurrence according to size of host and dates of capture.

OCCURRENCE OF PARASITES IN QUinNat SALMON FROM SACRAMENTO RIVER.

According to dates of capture.

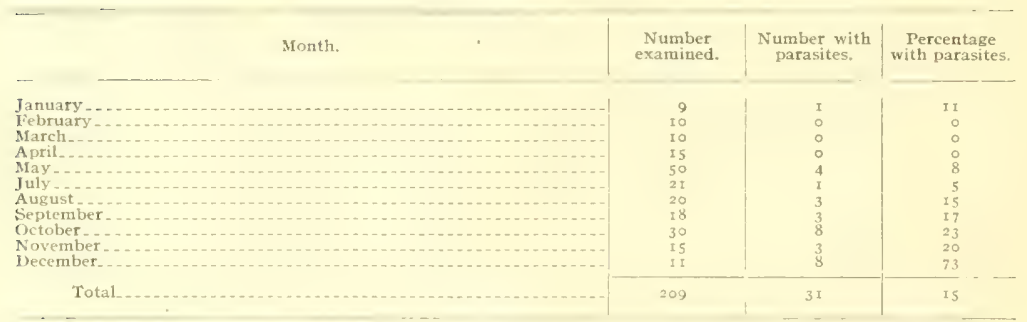


OCCURRENCE OF PARASITES IN QUinNat SALMON FROM SACramento RIVER - Continued. According to size of fish.

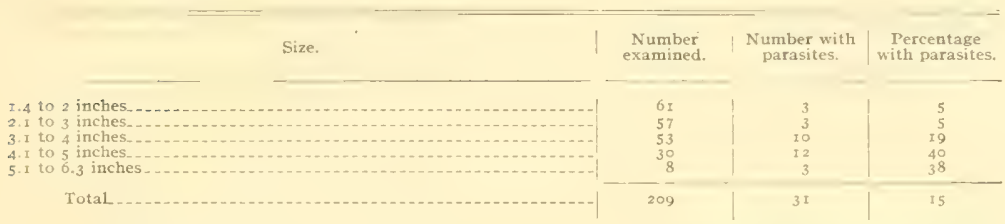

It will be noted that the percentage of infestation increases rapidly with the size and age of the fish, but this would naturally be associated with the more extensive feeding of the older and larger fish, whether in fresh or salt water. In the absence of comparative data for salt water forms to contrast with these of summer residents in fresh water, it is not allowable to attribute this condition to the delayed migration of these fish, as Rutter does. From brackish-water stations 20 young salmon were examined and parasites found in 3 only. This number is too small to be available for comparison with those fresh-water forms noted above. Unfortunately no further data are available concerning the varieties of parasites found either in the adult or in the young specimens. It is probable that the adult parasites are the same as certain forms to be discussed later from the Alaska salmon.

OBSERVATIONS ON THE SEBAGO SALMON.

\section{SPECIFIC RELATIONSHIPS}

The Sebago salmon is regarded by some as merely a landlocked variety of the Atlantic salmon, Salmo salar, found both in European streams and in the rivers of Maine and northward. By others it is viewed as a separate species, Sulmo sebago, but in any event closely related to the former. In their extensive catalogue of North American fishes, Jordan and Evermann (1896) include all these forms in the single species Salmo salar Linnæus, speaking of its range as follows:

North Atlantic, ascending all suitable rivers in northern Europe and the region north of Cape Cod to Hudson Bay; formerly abundant in the Hudson and occasional in the Delaware, its northern limit in the Churchill, Albany, and Iloose rivers, flowing into Hudson Bay; sometimes perfectly landlocked in lakes in Maine and northward, where its habits and coloration (but no tangible specific characters) change somewhat, when it becomes (in America) vars. sebayo and ouananiche. Similar landlocked varieties occur in Europe.

Of the Lake Sebago form which I had the opportunity of studying and which these authors regard as a subspecies, Salmo salar sebago (Girard), they write as follows:

Smaller in size, rather more plump in form, and nonmigratory; not otherwise evidently different. Sebago Pond and northward; introduced into lakes in various parts of the country; seldom entering streams; reaches a weight of 25 pounds. 
It is important to notice that the same authors also recognize a second subspecies, and this may be the form from which were obtained the parasites reported by Stafford (1904) and already commented upon. Concerning this subspecies, Jordan and Evermann write that Salmo salar is-

represented in Lake St. John, Saguenay River, and neighboring waters of Ouebec by the landlocked Salmo salar ounnanishe McCarthy MS., new subspecies. Still smaller, rarely reaching a weight of $7 \frac{1}{2}$ pounds and averaging $3 \frac{1}{2}$. An extremely vigorous and active fish, smaller and more active than ordinary salmon, but so far as known not structurally different. Saguenay River, Canada (outlet of Lake St. John), and neighboring waters.

Were it possible to determine definitely whether the records of Stafford concern the oceanic form caught during its migration or the landlocked form, a more definite value could be placed upon his data. In the absence of such information one can not venture to use these records at all in the discussion of the biological problems concerned. What these problems are will be clearer after a more detailed consideration of the case.

\section{SOURCE OF PARASITES.}

In view of the close specific connection of the two forms, the Furopean salmon just considered and the Sebago salmon, a comparative study of their parasitic fauna is of unusual interest, especially since the Atlantic salmon spends the greater part of its life in salt water, and after its entrance into fresh-water streams in the course of its migration does not in most cases partake of any food. Consequently whatever parasitic guests it larbors must, as already explained, be of marine origin. The exceptions to this statement are due to accidental infection, and are both small in numbers and insignificant in variety and relative importance. On the other hand, the landlocked Sebago salmon never enters salt water. Its period of active feeding and growth is passed in inland waters, those of Sebago Lake in the case of the specimens we secured and examined. Whatever parasites it harbors are hence obtained in that lake, and are either pure fresh-water organisms or such as have been introduced with the host and subsequently acclimatized to a fresh-water existence. In the case of such parasitic species as undergo direct development, like many nematodes, the introduction of a marine parasite into fresh water involves the habituation of the free living stage, either egg or larva, or both, to the limnetic environment, and this is the identical process involved in the transfer of any free living organism from a marine existence to one in fresh water. In the case of parasites which manifest indirect development with change of host the case is much more complicated. Such parasités usually have one or more brief stages of free existence in the open water as egg, embryo, or larva, like those just referred to. But they also employ one or more intermediate hosts, in which certain parts of the development are passed. Now, either the same marine animals which serve as intermediate hosts in the sea must be found in fresh water also, or must be successfully 
introduced at the same time with the primary host and its parasites to which they are related, or, finally, there must be present in the fresh water other animals which can serve successfully as intermediate hosts. The interrelation is thus very complicated and the chance of achieving it so small that in most cases marine forms do not bring the majority of their parasites with them in the transfer to fresh-water existence. In other words, limnetic animals are less heavily parasitized than marine. For this reason the examination of so recent a migrant into fresh water as the Sebago salmon is of great biological interest.

At Lake Sebago only 7 specimens of the Sebago salmon were obtained and examined. These weighed, respectively, 2, 2, 2, 3, 51/2, 8, and 16 pounds. While the number examined was from one standpoint small, yet in view of the scarcity of the species in the lake it was fortunately large. The series was also representative of different ages, ranging probably over several years in growth. It seems likely that if marked variations in food materials were found such a range of specimens would indicate the fact through differences in parasitic infestation. Yet there was a striking uniformity in the records in the series. Furthermore, the fish were all examined very soon after capture, and thus any post-mortem wanderings, which certainly do influence the location of parasites collected from market fish, were largely avoided. No doubt there are rare parasites of this species which are not represented in this collection, but, all things being considered, it may be asserted with some confidence that the records give a true picture of the number and location of the parasites infesting them.

The parasites found are recorded in the following table:

RECORD OF PARASITES FROM SALMO SEBAGO.

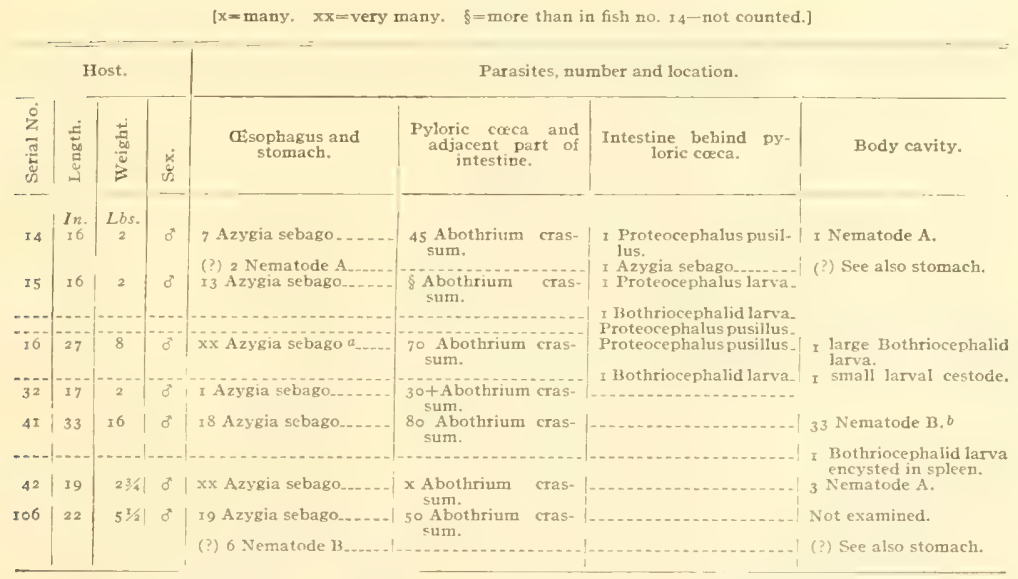




\section{A NEW TREMATODE PARASITE.}

Fivery one of the 7 fish examined contained specimens of a new trematode, which I have nanled Azygia sebago. It is relatively insignificant in size and difficult to detect amid the thick white nucus which lines the wall of stomach and oesopliagus. Not a single host was without this parasite, and several salmon sheltered considerable numbers; yet in most cases they were not seen in life, but only appeared after the stomach and its contents had been agitated in a preserving fluid. Careful examination of the débris then never failed to disclose some specimens of this worm. Moreover, it was the only species of trematode that was found in the Sebago salmon. The description of the species may properly precede a discussion of its biological characteristics.

The genus Azygia was established by Looss (1899, p. 569) to include a wellknown I uropean species, Distomum tereticolle Rudolphi, which was made the type of the new genus. It was also the only species in the genus; for, as Looss remarks, he had not been successful in finding among the flukes that he knew any form which could be included naturally with the old species, Distomum tereticolle. There are at the disposal of the student several good descriptions and delineations of the old species, Azygia tereticollis Rudolphi, so that it is possible to determine with precision its structural features; the best of these descriptions is undoubtedly that by Looss (I894).

The new species, Azygia sebago, ${ }^{a}$ is much smaller than the older form, measuring $10 \mathrm{~mm}$. in maximum length and averaging 5 to 6 , or less often $8 \mathrm{~mm}$., in well-developed specimens. Fortunately, I have a large range of sizes, from such as are only barely, over I mm. in length to the maximum noted, so that it was possible to follow the changes accompanying the assumption of the adult form. Specimens $2.85 \mathrm{~mm}$. long have not yet produced ova.

The general form of the body is cylindrical, bluntly rounded at the anterior end, and tapering slightly toward the posterior end, which, however, is ultimately rounded off. The body is regularly divided into two regions by a shallow furrow at which the direction of the long axis changes more or less (fig. I), giving the worm in lateral aspect much the appearance of a can-top tightener. While the relation of the regions is very variable, at times forming almost a single straight line and again standing at a considerable angle with each other, yet one can make out these conditions even in specimens which are poorly killed and badly distorted. The anterior region assumes the form of an ellipse surrounding the two suckers. This region changes relatively little in size with growth. In one of the smallest specimens measured ( $1.6 \mathrm{~mm}$.) the distance between the

a During the spring of 1908 two of my students, Messrs. W. N. Anderson and H. B. Boyden, made a study of this form and prepared a partial report on its structure, to which I am indebted for some of the data in the following description, and also for two figures. 
centers of the two suckers was $0.5 \mathrm{~mm}$. In one Io $\mathrm{mm}$. long this distance measured I mm.

The posterior region is nearly a perfect cylinder until shortly before the tip, where it tapers somewhat. In some specimens the posterior end is considerably inflated and appears semitranslucent. This is undoubtedly due to the distended condition of the excretory reservoir, which inhibits contraction of the circular muscles in the portion of the skin adjacent to it.

The breadth of the body varies according to the degree of contraction, but may be estimated in general as from 0.7 to $\mathrm{I} \mathrm{mm}$. An immature specimen $2.85 \mathrm{~mm}$. long measured $0.65 \mathrm{~mm}$. in breadth between the suckers, $0.6 \mathrm{~mm}$. behind the acetabulum, and $0.52 \mathrm{~mm}$. behind the posterior testis. An immature specimen only $1.6 \mathrm{~mm}$. in length measured $0.32,0.28$, and $0.21 \mathrm{~mm}$. in breadth at the same points. In cross section the body is round or very slightly oval.

The oral sucker is subterminal and its opening looks almost directly ventrad. It is rather conspicuous, and in an average specimen measured $0.68 \mathrm{~mm}$. in antero-posterior diameter and $0.67 \mathrm{~mm}$. transversely. The depth in the same specimen was $0.6 \mathrm{~mm}$. The orifice is nearly circular, though often appearing slightly flattened along the posterior margin. In an immature specimen 2.85 $\mathrm{mm}$. long the oral sucker measured $0.35 \mathrm{~mm}$. in antero-posterior diameter and $0.4 \mathrm{~mm}$. laterally; the orifice measured 8 o by i $50 \mu$.

The ventral sucker or acetabulum is usually distinctly smaller than the oral. In the extreme case it appears about equal in size or, on the other hand, only about half as large. Ordinarily it is prominent, but in short, thick specimens it is almost hidden, whereas in elongated, slender specimens it projects so far as to appear almost pedunculate. It is also often slightly oval in a transverse plane. In an adult specimen it measured $0.57 \mathrm{~mm}$. in antero-posterior diameter and $0.69 \mathrm{~mm}$. laterally. In a specimen $2.65 \mathrm{~mm}$. long the corresponding measurements were 0.3 and $0.33 \mathrm{~mm}$., and the orifice measured 52 by $80 \mu$.

The alimentary canal opens in the oral sucker, close behind which lies the pharynx without any prepharynx between the two. The pharynx measures $0.2 \mathrm{I}$ by $0.13 \mathrm{~mm}$. It is often seen in the vertical position represented in the figure of Messrs. Anderson and Boyden, which I have taken the liberty of copying liere. The oesophagus is very short and it often proceeds anteriad from the upright pharynx, as shown in the drawing (fig. 3, pl. cxxi). At its tip start the two branches of the intestine, which also usually extend forward a short distance and then turning posteriad continue almost to the extreme posterior tip of the body. These crura being longer than the body in the usual specimen are thrown into folds, which often appear as if the canal possessed irregular outpocketings, such as one finds in Paragonimus. Observations both on the living material and 
on serial sections show positively that such is not the case, but that the crura are simple tubes. The number of folds, twists, and turns depends upon the degree of contraction and usually appears greatest between the acetabulum and the ovary.

The excretory system is very characteristic of the genus Azygia. An elongate carrot-shaped collecting reservoir or bladder extends from the excretory pore, which is located at the posterior tip, through the center of the body anteriad to the posterior testis. The wall is heavy and is thrown into folds which appear at intervals projecting slightly into the cavity. From the anterior end of this reservoir two tubes pass off, right and left, which are at the start dorsal to the posterior testis; they soon pass toward the ventral surface, but cross the acetabulum on its dorsal aspect and dorsal to the oral sucker and are reflected posteriad. During their entire course they lie within the intestinal crura and usually ventrad to it. Their heavier walls indicate clearly that these conspicuous tubes are more nearly analogous to the collecting reservoirs of other flukes than to the delicate excretory vessels which here also are seen connecting with the tubes and the reservoir at various points.

The three germ glands, the ovary and two testes, lie close together in a longitudinal row distant from the anterior end about two-thirds the length of the worm. The ovary is most anterior and smallest of the group. An unusual morplological feature is the inclusion of the shell gland, a small yolk reservoir, the ends of the yolk ducts, and the first coils of the uterus within the same capsule that incloses the gland proper (fig. 6, pl. cxxi). The relation of the ducts as worked out by reconstruction is represented in figure 5 after the studies of Messrs. Anderson and Boyden. This resembles closely conditions as shown by Looss (I894) for A.tereticollis, although I do not find that he has noted the massing of organs within a common capsule. The uterus extends forward in numerous short coils which all lie within the intestinal crura until at the acetabulum it merges into a short, heavy-walled metraterm. The latter passes dorsal to the acetabulum and ventral to the cirrus pouch into the genital cloaca, with an inconspicuous genital pore located just anteriad to the acetabulum.

The vitelline glands lie along either side of the worm exterior to the intestinal crura. They begin a little behind the level of the acetabulum and extend to a point about halfway from the posterior testis to the end of the body. This constitutes perhaps the most striking morphological difference between this species and Azygia tereticollis, in which the vitellaria do not pass posteriad of the posterior testis. This conspicuous difference in the extent of the vitellaria enables the student to differentiate the two forms at a glance.

Attention should be called to the fact that on account of this structural feature a correction must be made in the generic description of Azygia, in which 
stress was originally laid on the extent of the vitellaria. The condition of the vitellaria in the older species has also been employed by Pratt (I902) as a characteristic of the genus in elaborating his key for the determination of the flukes. Although typically a member of the genus Azygia, the present form would fall in another genus according to the terms of that synopsis. No one who sees a specimen or reviews the structure of this form can doubt its relationship; the precise extent of the vitellaria is evidently a subordinate feature, and as such of specific rank only.

The follicles of the vitellaria are distinct, regularly oval bodies, lying in two longitudinal rows on each side with a more or less conspicuous break opposite the ovary between the anterior and posterior series. The follicles measure from 0.06 to 0.07 by 0.03 to $0.0+\mathrm{mm}$. The symmetry of the rows is in places interrupted by extra follicles, making at such points three rows of follicles instead of two as usual. The ducts from the anterior and posterior series unite opposite the ovary to form a common transverse duct which at the center of the body joins its fellow from the opposite side. At the point of union there is a small yolk reservoir. As already noted, this is included within the common capsule which surrounds the ovary and is ordinarily not visible except in sections. Laurer's canal is present and opens on the dorsal surface just posterior to the ovary. It does not have the enlargement ordinarily called a seminal receptacle, but is usually somewhat coiled and lies on the left side of the ovary. This may be an adaptation to the extremie variations in length so characteristic of this worm.

The eggs are small; an average of 50 measurements places their size at 48 by $27 \mu$, which is slightly larger and broader than those of A. tereticollis, according to the measurements given by I,ooss (1894).

The testes are oval bodies lying one directly behind the other and that behind the ovary. The three organs are separated only very slightly from each other. The outline of the testes is smooth and measures 0.42 to 0.46 by 0.59 to $0.6 \mathrm{~mm}$. with the major axis transverse. One can usually distinguish that the two are not equal in size. The coiled seminal vesicle and a poorly developed cirrus with prostate lie in a common connective tissue capsule, the cirrus pouch, which stands immediately anterior to the acetabulum. The pouch measures about 0.23 by $0.17 \mathrm{~mm}$. in diameter. It opens anterior to the metraterm into the genital sinus already mentioned.

One histological feature deserves consideration here because of its conspicuous character. In sections of Azygia sebago one notices certain muscle elements which are so prominent and regular as to deserve almost the name of a layer; they occur within the parenchyma, far removed from the usually recognized dermal layers and at a point where ordinarily one finds only scattered 
dorso-ventral or oblique fibers which are not subject to any regularity in arrangement. These are longitudinal fibers extending from the oral sucker throughout the entire length of the distome, as is clearly seen in a frontal section (fig. 4, pl. cxxi). In position they lie one-fourth to one-fifth the radius of the section distant from the external surface. The cross sections of these fibers show them to be much heavier than the other muscle elements and to occupy an oval zone parallel to the outer surface of the body. They divide the body accordingly into a cortical and a medullary portion. The vitellaria are the only conspicuous organs which lie in the cortical layer. This muscle layer is undoubtedly related to the marked contractions of the fluke which have already been commented upon. Unfortunately I have no material available from which to determine whether similar fibers also exist in A. tereticollis. Looss (ig04) does not mention them.

The relations of oral sucker, pharynx, and crura, the convolutions of the intestinal branches, the coils of Laurer's canal and of various ducts and the sinuous course of the collecting tubes in the excretory system all point toward the variable extensibility of the worm. Differences in caliber and in the distance between organs also indicate the same. Observations on the living parasite serve to show that it is constantly extending and contracting the body to such an extent as to double or halve the length within a few seconds of time. In fact, I have never before observed a form which indulged in such energetic twisting and contracting. This habit renders any observations on the living worm very difficult.

Looss $(1894, \mathrm{p} .7)$ comments on the active migration of A. teveticollis after the death of the host, a feature previously recorded for $D$. cylindraceum by Braun ( 1890 , p. 568). A. sebago manifests the same tendency in the most marked degree. 'The normal seat of this parasite I feel sure is the stomach, and perhaps the oesophagus also, but even a slight delay in the examination of the host resulted in finding single specimens well down the intestine as well as up in the pharynx and even among the gill filaments. In one case a salmon caught late in the day was kept overnight to be photographed, as it was a peculiarly fine specimen. When the viscera were examined, about twenty hours after the capture of the fish, my field notes record that there were 36 distomes in the air bladder and that they were scen coming in through the ostium with mucus from the oesophagus. Other specimens were found in the pharynx and gill cavity and one even in the body cavity. The last can be attributed no doubt to some tear in the alimentary lining which permitted the fluke to make its way unhindered into what is ordinarily a closed cavity. In still another salmon which had gorged itself on smelts my field notes contain com- 
ments on the activity manifested by these distomes, which climbed about on the smelts and in them as they lay half digested in the stomach of the salmon.

This was so noticeable that I turned my attention at once to the smelt ${ }^{a}$ to ascertain if perchance it played any part in the life history of the distome. In all, I have records of 52 smelts examined, and in 46 of these were found specimens of Azygia sebago. The parasite occurred in the stomach only and the infestation was small, from I to 14 distomes being found in each host, with an average of only 4 to a fish. In most cases the parasites which were taken from the stomach of the smelt were immature, not having yet reached that size at which the production of ova begins; they were on the average 3 to $4 \mathrm{~mm}$. long, or in some cases even smaller, running from 1.5 to $2.5 \mathrm{~mm}$. in length. Single specimens reached a length of 6,7 , and even $10 \mathrm{~mm}$. In one case, indeed, there were none shorter than $6 \mathrm{~mm}$, and the specimens varied from that to $10 \mathrm{~mm}$, so that one can not fairly maintain that they never reach the size attained in the salmon. Nevertheless, after the account is cast up the average shows distinctly that the distomes do not reach their full size in the smelt and, so far as collections made during July and August can indicate, those taken from this host are usually small in size and sexually immature. I did not obtain any information as to the source from which the smelt acquires its infection, but in view of the universality with which smelt form the food of the salmon in Sebago Lake the latter undoubtedly owe to them the major portion of their infestation with this parasite.

The host record of Azygia sebago is even yet unfinished. In the course of my work numerous other fish from these same waters were examined. In young specimens of Esox reticulatus 6 to 16 inches long I found this same parasite reasonably abundant. To be sure, they seemed to average somewhat longer, being Io to $12 \mathrm{~mm}$. in length in material from one host and Io to 14 or even $\mathrm{I} 8$

a This fish I am compelled to designate under the name Osmerus mordax (Mitchill), as Jordan and Evermann (1896) do not recognize the Sebago smelt as a separate form, saying of the species "Atlantic coast of the United States from Virginia northward to Gulf of St. Lawrence, entering streams and of ten landlocked." I am inclined to think that even in Sebago Lake there are two smelts. My atten. tion was first directed to this possibility by Dr. W. C. Kendall, who, recalling our previous discussion, writes as follows in a recent letter:

"You may recall that there seem to be two forms in the lake differing somewhat in size and habits. The large form, which is the one that we caught with hook and line, is nearer to the marise smelt. The small form is the one that we found in the salmons' stomachs. You will doubtless recall that the principal food, when any at all was found in their stomachs, of the large form was small fish, generally young smelts. Our examinations of the stomach contents of the small form show Entomostraca almost exclusively. This difference is indicated also by the gillrakers, which are more numerous in the small form."

These distomes occurred equally in both sorts of smelt and those from the smaller smelts were larger than those from the larger fish. This is, of course, a mere accident, but it serves to show that the two types of smelt conduct themselves alike toward the parasite. 
mim. long in that from another host. In the latter it was noticeable that the suckers protruded very conspicuously and the body was much smaller in caliber than in the specimens from the salmon and the smelt. Yet in the absence of any structural differences I am forced to conclude that this contrast in size and general external appearance is due to some slight difference in the technique employed or in the condition of the parasites when they were preserved. This is all the more probable when one considers that in one case the specimens from Esox were identical in appearance with those from the salmon. This parasite was found in all but one of the dozen specimens of Esox reticulatus examined, being present in the stomach in numbers of $x$ to 80 in each host. In two cases a single specimen was found in the intestine, perhaps due to some post-mortem wandering on the part of the parasites. In 4 specimens of Anguilla chrysypa out of 9 examined I also found Azygia sebago in the stomach, but in small numbers only, averaging 3 to each host. Finally 2 of these distomes were found in a single Perca flazescens, here also in the stomach.

In order to give a ready comparison, I append hereto a table of similar measurements from a series of this distome taken from the various hosts mentioned. The difference in length indicates in part age and in part method of preservation. In fact, it is difficult to achieve any uniformity among specimens so exceedingly active as this species.

MEASUREMFNTS OF AZYGIA SEBAGO.

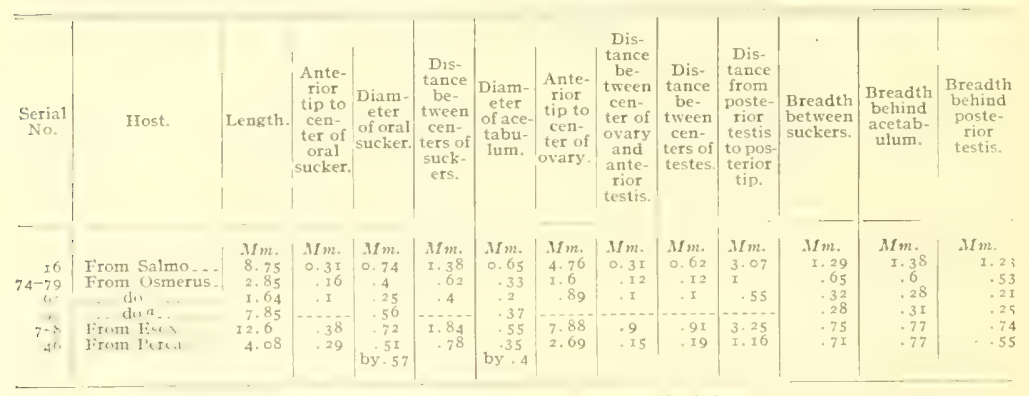

a Much elongated; poor technique; preserved by helper.

The question naturally presents itself, Has this form been seen by others previous to the present date? 'The records on the subject are scanty, but they throw some light on the question. 
Leidy has described ( $85 \mathrm{x}, \mathrm{p} .206$ ) a form as Distomum terreticolle ${ }^{a}$ Rudolphi, which Pratt (I902, p. 957) lists as Azygia tereticollis (R.) L.eidy. The original description is as follows (Leidy, $185 \mathrm{r}, \mathrm{p} .206$ ):

Distomum terreticolle, Rud. Entoz. Syn., p. IO2; Dujardin, Hist. Nat. des Helm.; Diesing, Syst. Helm., p. $35^{8}$.

Body subcylindric, light flesh color, posteriorly rounded. Ventral acetabulum (3/4 line) $1.6 \mathrm{~mm}$. behind the oral $(\mathrm{T} / 3$ line $) 0.7 \mathrm{~mm}$. in diameter. Oral acetabulum $(\mathrm{I} / \mathrm{t}$ line $0.5 \mathrm{~mm}$. $0.7 \mathrm{~mm}$

Length (8 lines) $16.8 \mathrm{~mm}$; breadth posteriorly ( $1 / 2$ line) I mm., anteriorly ( $i / 3$ line)

Habitation.-Stomach of Esox reticulatus Lesueur.

Remark.- The generative aperture is placed immediately in advance of the ventral acetabulum. When the animal contracts, the two acetabula are nearly brought into contact.

The description is scanty, and yet one can say with some assurance that the form before Leidy was not the European species named by Rudolphi and discussed by a long series of authors, of whom Looss (r894) has given the most complete description with truly admirable figures. Leidy's specimen is much too small for average adults of Azygia tereticollis, which is, moreover, cylindrical instead of broader posteriorly, as was Leidy's worm. Again, Azygia tereticollis has the oral sucker larger than the acetabulum, whereas in Leidy's form the reverse is true. Finally the suckers in Leidy's form do not agree at all in size with the suckers in Azygia tereticollis, as described by Dujardin and others.

It is somewhat more difficult to say whether the form before Leidy was the same as that I collected in the Sebago salmon. In size the two are not very different, although Leidy's was larger. Other measurements do not agree at all well. The sizes given for the suckers are just about reversed. The final determination of this point, however, must await a reexamination of Leidy's original material.

The only other reference to the occurrence of Azygia on this continent, so far as I know, is the brief note of Stafford ( 1904, p. 488), in which he records Azygia ${ }^{b}$ tereticollis Rudolphi from mouth, pharynx, œsophagus, and stomach of Esox lucius Linnæus, Lota maculosa Le Sueur, and Ameiurus nigricans Le Sueur. Absolutely the only data concerning the worm which Stafford records is the size, I 2 by I mim. Now, this does not agree with adults of A. tereticollis, for Looss (1894, p. x8) says of that species that the first eggs are not set free into the uterus until the worm is 8 to ro mm, or more in length, and these are uniformly abnormal and defective. In another place he remarks (I $894, \mathrm{p} .7$ ) that in most cases eggs are found in worms $12 \mathrm{~mm}$. long, although in scanty numbers. I am of the opinion that Stafford did not have before him the true A. tereticollis

$a$ The text by error contains terrcticolle for the specific name instead of tercticolle.

$b$ Unfortunately, Stafford spells the genus Azigia and the species tercticolle. 
and incline to the belief that the form which he observed may have been the species under discussion.

The European species, Azygia tereticollis, has been reported from Esoxlucius, Lucioperca sandra, Lota vulgaris, Trutta variabilis, Salmo trutta, Salmo fario, Salmo hucho, Salmo alpinus, and Salmo salar. All of these save Salmo salar are fresh-water fish, and the parasite may be regarded as a characteristic of freshwater species. The American species, Azygia sebago, I found in Salmo sebago, Esox reticulatus, Osmerus mordax, Anguilla chrysypa, and Perca flavescens. Stafford recorded what may have been the same from Esox lucius, Lota maculosa, and Ameiurus nigricans. These include strictly fresh-rvater forms, landlocked species, and one migratory tish, but inasmuch as the records have been taken in fresh water even the last host does not constitute any evidence against the freshwater habitat of Azygia sebago. Its congener, Azygia tereticollis, found by McIntosh in the salmon of the Tay, formed part of the evidence that this host feeds during its fresh-water residence. Equally here we may regard $A$. sehago as a fresh-water element acquired by its host since the latter became landlocked in Lake Sebago. The presence of the parasite in several other characteristic fish of the same water basin is clear evidence of the sources from which it might have come.

\section{CESTODES.}

Cestodes constituted the most conspicuous element of the parasitic fauna. Every salmon opened contained a mass of large worms in the pyloric region. They lay with the head and anterior portion of the body in a pyloric coecum usually at or near its tip. The worms were large and the body was thrown into loops which occupied the initial cocum and folded through the intestinal canal into other coca, often crowding them full apparently to bursting. Viewed from the body cavity, even before the viscera were opened, one could distinguish the coca which contained the parasites by their opaque, chalky appearance in distinct contrast with the translucent character of those coeca in which there were no tapeworms. When the intestine was opened it appeared full of the cestodes, which protruded in loops hanging from the coeca into the cavity or crossing into other cueca in a tangled mass, in several cases large enough to distend the wall conspicuously. The anterior cœeca were those primarily or chiefly occupied by the worms and although often the entire cavity of the intestinal canal was crowded full of parasites, it was noteworthy that they rarely if ever entered any of the posterior coeca. When few worms were found they lay with the scolices at least in the coeca of the most anterior region.

The species to which I have referred in the preceding paragraph is the wellknown Bothriocephalus infundibuliformis, according to Luhe (1899) more correctly designated Ahothrium crassum, which is so common in the Atlantic salmon 
from various parts of Europe. Of its occurrence in the Rhine salmon, where it is found in 42 per cent of the specimens examined, in 9I per cent of the Baltic salmon, in 26 per cent of the Tweed salmon, in most of the Tay salmon and of the Irish salmon, enough has been said in the historical survey. It is a typical salmonid parasite, and is found even in eight species of that family which inhabit fresh water. Its presence in the landlocked Salmo scbago, which confines its life cycle to fresh water, is hence not surprising. Evidently the life cycle of the species permits of easy adaptation to a fresh-water existence, for I have to report its occurrence not only in the host under discussion, but also in another prominent American salmonid, the Great Lakes trout, Cristivomer namaycush (Walbaum). It was found abundantly in specimens of this host which I examined in July and August, I894, at Charlevoix, Mich. From 30 to 80 tapeworms of this species were present in each Sebago salmon, and neither size nor age played any evident part in determining the degree of infestation. Absolutely every one of the salmon taken was infested. In considering the possible life history, I naturally turned to the Sebago smelt as the host of the larval form, probably a plerocercoid, and examined a number of these fish with great care, but was unable to detect the larva, if indeed it was present. Nothing was discovered which throws any light on the life cycle. It is worthy of note that all of these parasites were full grown; not a single specimen was found which was not discharging ripe proglottids. Consequently the infestation must have taken place somewhat earlier in the year. It would take observations at other months to determine when; and the food at that time would evidently be the source of the parasite.

In addition to this dominant species some other cestodes were also recorded. A few fragments of a small species of Proteocephalus were found in each of four hosts, and a larval form, which probably belongs to the same Proteocephalus, was obtained in each of two hosts. Two different bothriocephalid larvæ of small size also occurred each in a single salmon. The four forms just mentioned were all found in the intestine.

The insignificant size of a new species of Proteocephalus found and the small number of individuals present in any one host resulted in its being overlooked at first, and it may easily have been present in more hosts than shown by the records. It was found in four out of the seven salmon examined, but in one case only a few loose proglottids were discovered by accident among material from the intestine. A careful examination in comparison with the descriptions of known species leads me to the view that this is a new species to which the name Proteocephalus pusillus may be given. The salient points in the description of this new species are as follows:

Proteocephalus pusillus nov. spec.-Adult cestode with short strobila, measuring only 30 to $50 \mathrm{~mm}$. in length. Proglottids scanty, segmentation 
distinct. Head much contracted. Neck I to $1.5 \mathrm{~mm}$. long by $0.2 \mathrm{I} \mathrm{mm}$. broad. First proglottids $0.09 \mathrm{~mm}$. broad, changing gradually until in mature proglottids the length greatly exceeds the breadth. Ripe proglottids measure 0.84 to 1.4 $\mathrm{mm}$. long by 0.18 to $0.35 \mathrm{~mm}$. broad. Terminal proglottids present and fertile. Sexual organs typical for Proteocephalus; uterus median, with ro to 14 lateral outpochetings on either sicle. Testes numerous, within vitellaria. Genital pore lateral, one-third to two-fifths of length of proglottid from anterior margin of same. Ovaries bilobed, median isthmus indistinct, anteroposterior diameter nearly equal to breadth of both lobes. Only a few specimens obtained from a single host species, Salmo sebago.

This species approaches most nearly to $P$. ocellata and $P$. perce among known species. Unlike the new species, however, both of these older forms have a fifth sucker, fewer lateral uterine outpocketings, a longer neck, differently shaped ovaries, and markedly different proglottids.

In specimens with developed proglottids the head was so much contracted or distorted that any special description would be of little value. One could easily observe the general features characteristic of the genus. There was no well developed terminal or fifth sucker, and the end organ, which is known to replace it in many forms of this genus, was inconspicuously developed, if present. Personally, I incline to the view that on more careful examination this structure will be found in all species, even those in which its absence has been made a matter of record. Accordingly, not much weight can be put in its presence or absence in any individual case. ${ }^{a}$

Three plerocercoid larvæ or young cestodes were found in company with Proteocephalus pusillus, which I regard as young forms of this species. The largest came from the salmon which was most heavily infected with this cestode parasite. It was 3.I $5 \mathrm{~mm}$. long and had begun to assume clearly the appearance of an immature cestode. The head measured $0.3 \mathrm{~mm}$. wide by $0.26 \mathrm{~mm}$. long, and the suckers o.I4 $\mathrm{mm}$. in length by $0.1 \mathrm{Imm}$. in width. The neck was slightly narrower than the head, but was not clearly set off from the body, which was very uniform in diameter and measured $0.25 \mathrm{~mm}$. in average width. The posterior end of the body was swollen into a rounded knob about $0.35 \mathrm{~mm}$. broad and of approximately the same length. This feature was evidently produced by a powerful contraction of the terminal region of the body. In and near it one could see very indistinct indications of proglottid formation. In form, size, and general aspect this young cestode was in full agreement with the anterior regions of the mature cestodes of this species with which it was

$a$ For a more definite discussion of this peculiar structure so variable in development in the cestodes of this genus, I would refer to a paper now in press by my student, Mr. George R. La Rue, to whom I am indebted for a comparison of this material from Salmo sebago with preparations of other species of Proteocephalus 
associated. The head, which was not contracted, showed on careful study the delicate outline of a rudimentary end organ. While such a structure was not demonstrated in the mature individuals described above, one can say positively that if present it could not have been seen owing to the greatly contracted condition of the adult scolices. I believe that its presence will be demonstrated in more favorable specimens. The complete agreement of this largest larva with the mature specimens in all other features compels me to regard both as different stages in the development of the same species.

The other larvæ were still in early stages of development, and probably had been ingested by the salmon at a very recent date. Their relationship is not so clear in all respects, and yet I do not hesitate to associate with the new species of Proteocephalus a plerocercoid or young cestode obtained from the same host as the adult worms and the older larva just described. The head is broadly conical, without furrows, and measures $0.3 \mathrm{~mm}$. in breadth. The suckers measure 60 to $75 \mu$ in diameter. There is no rostellum or fifth sucker to be found, while the end organ is so poorly developed as to be visible with difficulty and only under the most favorable circumstances. The neck is nearly as broad as the head. In general appearance this larva resembles the adult cestode and the older larva previously described. With some reserve one may also assign to this species a single plerocercus taken from another specimen of Salmo sebago. The head, which measures only $150 \mu$ in breadth, is shaped like that of the young cestode and like it is without rostellum or fifth sucker, while the end organ is difficult to demonstrate. Neither furrows nor ridges are seen on the larva, which has a total length of I.I $4 \mathrm{~mm}$. The sucker measures only 30 to $45 \mu$ in diameter. The neck is slightly narrower than the head. This form certainly belongs to the genus Protecephalus and probably to the species already described.

From the scantiness of the material obtained one might infer that the Sebago salmon is only a casual host of the species. Yet I did not secure this parasite from any other fish in Lake Sebago and adjacent waters, and I have not met it in fish examined in other places. The presence of larve in different stages of development with only a few adult specimens in any one host, although some were found in the majority of the salmon examined, would rather favor the view that the cestode was a regular though infrequent parasite of this host.

Sparganum sebago, nov. spec.-In addition to the cestodes already mentioned, there are to be noted two specimens of bothriocephalid larvæ which deserve more extended mention.

The first was taken from the spleen of one salmon. It measured $25 \mathrm{~mm}$. in length and $1.8 \mathrm{~mm}$. in maximum diameter. There is no neck, but the body 
increases slightly in breadth for about one-quarter of the entire length and then tapers gradually to the posterior end, which is rounded off. 'The body is clliptical in cross section without any segmentation, but with numerous rather prominent annular wrinkles. It seemed as if the margins of the body were thicker than the center. The head was retracted. (Fig. 7 and 8, pl. cxxi.)

The second specimen (fig. 9 and ro, pl. cxxi) was found free in the body cavity of another salmon. It was $36 \mathrm{~mm}$. long and $0.86 \mathrm{~mm}$. in breadth. The body was somewhat thicker than in the other specimen, but less deeply wrinkled, and the center was certainly thicker than the margins. In this, as in the color and texture, it appeared different from the first specimen. There was no neck. The head measured $0.31 \mathrm{~mm}$. in transverse diameter and $0.43 \mathrm{~mm}$. from the apex to the base of the grooves, which were keyhole shaped. The groove measured $0.25 \mathrm{~mm}$. in transverse diameter at the anterior end and 0.09 near its posterior end. In spite of the differences in appearance noted above it is easily possible that the two specimens belong to the same species and I have preferred to list them for the present under a single heading, naming the form Sparganum scbago.

A word should be said with regard to other hosts for these cestodes. Abothrium crassum was not found in any other fish examined at Sebago Lake. Larvæ of Proteocephalus and of some bothriocephalid were found in a very few cases in other fish taken from these waters. There were none, however, of which it could be said with reasonable certainty that they were the same as the forms collected from the Sebago salmon and mentioned above. The question of the occurrence of such salmon parasites in other hosts of this region must be left entirely open for the present at least.

\section{NEMATODES.}

Nematodes were not common. They occurred only in half of the specimens of salmon examined and were not abundant. In one salmon 33 of these worms were obtained, but in the other three only a dozen all told. Accordingly they seem to play only a minor part in the parasitic fauna of the Sebago salmon. They belong to two or three separate species, which are radically distinct. Thus far I have not been able to make a satisfactory determination for any of them, owing to the scantiness of the material and to its unsatisfactory condition. This much can be said: They do not belong to any of the species, or even to the genera, heretofore recorded for the Atlantic salmon. A few notes may be added here concerning these forms.

A small nematode was found in the stomach and in the body cavity of two salmon. In all there were only six individuals of this species. I have not been able to satisfy myself that the individuals recorded as from the stomach really belong there, but incline to think that they were adherent to the external 
surface of the stomach and passed unnoticed when that organ was opened and shaken in a preserving fluid in order to collect the small specimens of Azygia sebago concealed in the gastric mucus. Subsequently they were found in the material obtained in this process. They are probably true parasites of the body cavity. Since an approximate determination may easily be misleading I forego all attempt to name this form and designate it for the present simply as "Nematode A."

The group of 33 nematodes obtained from the body cavity was a source of great surprise. These worms are identical with a form found in very large numbers in the Alaska salmon. Since, however, this species is to be discussed at letrgth in the section of my report which deals with that host, it seems wise to omit here any details and refer to the worm simply as "Nematode B." It is a large form belonging to the Filariadx, but so delicate that it is almost impossible to obtain perfect specimens, and it has thus far proved beyond my skill to preserve any in a complete condition. It has been an exceedingly interesting object of study and will receive at an early date, in connection with the records of the Alaska salmon and its parasites, that detailed consideration which its frequence and its interest warrant. The six nematodes recorded from the stomach were collected and preserved by an assistant. They are in very poor condition, so that any determination can hardly be more than an impression, but the only real reason why I hesitate to refer them to the same species is that in all the thousands of specimens from nearly 200 hosts which I handled in the course of my investigations on the Alaska salmon I never once found the species anywhere save in the body cavity. It is not impossible that these specimens were reported from the stomach through some error. As repeated examination is bringing me more and more firmly to accept the identity of this lot with those which I collected personally from the body cavity of the Sebago salmon and of the Alaska salmon, I am being forced to assume the existence of some error in recording them as from the stomach.

In any event, it may be said that not more than three species of nematodes are present in the Sebago salmon and that these species are only infrequently and scantily represented in this host. None of the nematodes were found in any other fish examined at Sebago Lake, nor are they known to me from fish of any fresh-water locality in this country. Thus far also I have failed to find any reference in the literature which could be construed as indicating either of these forms.

\section{RÉSUMÉ AND CONCLUSIONS.}

The first general conclusion to be drawn from this study of the parasitic fauna of the Sebago salmon is that the total number of parasites recorded from this host is small. In all, there have been listed only I trematode, 2 cestodes, 4 (?) cestode larvæ, and 2 nematodes, or a total at most of 9 species 
of parasites. 'To be sure, the number of hosts examined was small, and this may account for the low total record. Two of these parasites, Azygia scbago and Abothrium crassum, were found in every fish examined, and each of six other parasites was found in two hosts. This may be compared with Zschokke (1896, p. 824), who records the parasitic census of Io salmon from the North Sea. In these ro fish were found ro species of parasites. A trematode and a cestode occurred each in 9 of the fish examined. The cestode was Abothrium crassum, the same species as that found in every Sebago salmon; the trematode was Distomum ocreatum, a purely marine form, and hence in sharp contrast with the abundant trematode in the Sebago salmon, which is a member of a characteristic fresh-water genus. This contrast, as well as several other details commented on in the previous pages, seem to indicate the fresh-water aspect of the parasitic fauna in the Sebago salmon.

The conditions in the Sebago salmon are all the more striking when one considers the forms which are not found among its parasites. Reverting first to the trematodes, one notices that the only genus represented here, Azygia, has been recorded from the Atlantic salmon in Europe only in a single case, while here its representatives were found in every host examined. On the other hand, Derogenes varicus, recorded from a good percentage of Furopean salmon in all localities, was not seen even once. The other distomes recorded by Furopean observers in various regions, and often as fairly frequent parasites of the salmon, are entirely wanting in Sebago salmon. Azygia is the only purely fresh-water distome found in European salmon; it is the only distome found in the Sebago salmon. The other distomes recorded in European salmon are purely marine species, or very largely so, but none of them occur in the Sebago salmon.

Among the cestodes conditions are identical. The common form, Abothrium crassum, is confined to salmonids, without reference to their habitat, and is as common in fresh-water species as in marine. On the other hand, those cestodes which are typically marine, like Rhynchobothrium paleaceum, Scolex polymorphus, and the several species of Tetrarhynchus, are absolutely wanting in the Sebago salmon. The various cestode larvæ are too little known to justify their consideration in this connection. They are not referable, even indefinitely, to either habitat. To this statement one must make two exceptions. Scolex polymorphus, recorded from the salmon in Europe, is typically marine, occurring in many sea fish, even though several species may be indicated under the single name. On the other hand, the larva of Proteocephalus is equally typically limnetic and it is recorded from the Sebago salmon only unless the single record of Tania sp. for a larva from the salmon in the Tweed should be referred to this form. In this group again it appears clear that the marine parasites of the European salmon are wanting in the Sebago species, that the only cestodes 
identical in the two forms are such as are clearly fresh-ivater species, and that the Sebago salmon contain at least one clearly fresh-water genus which is not reported from the corresponding European host.

Among the nematodes the evidence is less conclusive, since the amount of material is smaller; indeed, hardly enough to form a basis for any conclusions. At the same time, all the species which give to the parasitic fauna of the European salmon its marine aspect are entirely wanting here. Not a single specimen of Agamonema was discovered, although two species are found in the European salmon, and one of them, Agamonema capsularia, is very common. Both Ascaris and Echinorhynchus are unrepresented in the parasitic fauna of the Sebago salmon. Among the numerous species of each already recorded as parasitic in the European salmon three out of four are purely marine. Here again one notes that the marine elements in the parasitic fauna of the firopean salmon are wanting in the Sebago salmon. Possibly the large filariad found abundantly in the Alaska salmon, and reported also from one or two salmon taken in Sebago Lake, forms an exception to the general rule. As I have already noted, it appears to be marine in origin. This may be, however, a false argument, and the species may actually be one limited to this host or to the salmonid family, regardless of habitat. In this connection one naturally recalls at once the case of Abothrium crassum, which, from the observations on salmon in the North Sea and then in the Rhine, might be said to be a marine form, since it gradually disappears on the journey up the Rhine. But it occurs in hosts of purely fresh-water habitat, such as Salmo hucho in Europe and Cristivomer namaycush in the Great Lakes of North America. Evidently further information is needed before one can safely assign this nematode to a definite habitat.

Summing up all the evidence concerning the parasites of the Sebago salmon, one finds that four species are unknown in character, one only is possibly marine, one is a pure salmon parasite, and three are clearly fresh-water forms. The latter are also its most frequent and numerous guests. Furthermore, the Sebago salmon lacks every one of those parasites found in the European salmon which must be regarded as purely or largely marine, and possesses in common with its European congener only one characteristic salmon parasite and possibly also two fresh-water forms, which, though abundant in its own parasitic fauna, are very rare in that of its relative.

The parasitic fauna of the Sebago salmon manifests a striking fresh-water aspect, all the more unexpected in view of the marine character of that in the European salmon as demonstrated by Zschokke. One could hardly find a more convincing demonstration of the fundamental hiological relation between parasite and host.

The parasitic fauna of any animal is primarily a function of its habitat. 
BEAN, T. H.

\section{BIBLIOGRAPHY.}

1890. Report on the salmon and salmon rivers of Alaska, with notes on the conditions, methods, and needs of the salmon fisheries. Bulletin U. S. Fish Commission, vol. x, p. 165-208.

1893. Life history of the salmon. Bulletin U. S. Fish Commission, vol. xur, p. 2I-38.

BELLINGHAM, $O$.

1840. Catalogue of the Entozon indigenous to Ireland. Magazine of Natural History, n. S., vol. 4, I). 343-35 r.

1844. Catalogue of the Entozon indigenous to Ireland. (Reprinted.) Annals and Magazine of Natural History, vol. I4, p. $47 \mathrm{I}-479$

1844. On Irish Entozoa. Ibid., vol. 13, p. 167-174, 422-430; vol. 14, p. I62-165, $251-256$.

BraUn, $M$.

เ89o. Notiz über Auswanderung von Distomen. Centralblatt für Bakteriologie und Parasitenkunde, bd. 7, p. 568 .

1894. Vermes.-Trematodes. Bronn's Klassen und Ordnungen des Thierreichs, bd, w, abt. I.

DiEsing, C. M.

1851. Systema Helminthum, vol. ir. Vindobonx.

Drummond, J. L.

1838. Notices of Itish Fintozoa. Magazine of Natural History, n. S., vol. 2, p. 515-524, 571-577 $655-662,32 \mathrm{fig}$.

GOEZE, J. A. E.

1782. Versuch einer Naturgeschichte der Eingeweidewürmer thierischer Körper. 471 p., 35 pl. Blankenburg.

HAUSMANN, L.

1897. Ueber Trematoden der Süsswasserfische. Revue suisse de Zoologie, t. 5, p. I-42, I pl.

HOEK, P. P. C

I899. Neuere Lachs- und Maifisch-Studien. Tijdschrift der Nederlandsche Dierkundige Vereeniging, 2 de serie, deel vi, p $1_{5} 6-242,5$ pl.

Jordan, D. S., and EvERMANN, B. W.

1896. The fishes of North and Middle America. Bulletin 47, U. S. National Museum, pt. I.

LEIDY, J.

185x. Contributions to helminthology. Proceedings Academy of Natural Science, Philadelplia, vol. 5 , p. 205-210.

1871. Notices of some worms, Dibothrium cordiceps, Hirudo, Gordius. Ibid., vol. 23, p. 305-307.

Linstow, O, von

1878. Compendium der Helminthologie. Hannover.

1889. Compendium der Helminthologie. Nachtrag. Hannover.

Looss, A.

1899. Weitere Beiträge zur Kenntniss der Trematoden-Fauna Aegyptens, zugleich Versuch einer natürlichen Gliederung des Genus Distomum Retzius. Zoologische Jahrbücher, Syst., bd. I 2, P. 521-784, 9 taf.

1894. Die Distomen unserer Fische und Frösche. Bibliotheca Zoologica, hft. I6.

1907. Beiträge zur Systematik der Distomen-Zur Kenntniss der Familie Hemiuridæ. Zoologische Jahrbücher, Systematik, bd. 26, p. 63-180, 9 taf. 
LÜHE, M.

1899. Zur Anatomie und Systematik der Bothriocephaliden. Verhandlungen der deutschen zoologischen Gesellschaft, 1899 , p. 30-55.

19or. Ueber Hemiuriden. Zoologischer Anzeiger, bd. 24, p. 394-403, 473-488, 3 fig.

MCINTOSH, W. C.

1863. Notes on the food and parasites of the Salmo salar of the Tay. Journal Linnean Society of London, vol. 7, p. 145-154.

MONIEZ, R.

1881. Mémoires sur les Cestodes. I. Travaux de l'Institut zoologique Lille, t. 3, fasc. 2, 238 p., $12 \mathrm{pl}$.

MÜHLINS, P.

1898. Die Helminthen-Fauna der Wirbeltiere Ostpreussens. Archiv für Naturgeschichte, I 898 , p. I-I $18,+$ taf.

MÜLLER, O. F.

1776. Zoologiæ danicæ prodromus seu animalium Daniæ et Norvegiæ indigenarum characteres, nomina et synonyma imprimis popularium Havnix 1776. (Cited after Braun, 1894.)

1777. Zoologia danica seu animalium Danix et Norvegix rariorum ac minus notorum descriptiones et historia. 4 vol. Havnix. (First edition said to be 1777 ; that consulted was $1788-1806$.

1780. Om Baendelorme (Nye saml. af det Kgl. Danske Vidensk. Selsk. Skrift. Forste deel, Kopenhavn, I78I, p. 55. Deutsch im: Naturforscher St. XIv. Halle, I780, p. 129). (Cited after Braun, i 894.)

ODHNER, TH.

1905. Die Trematoden des arktischen Gebietes. Fauna Arctica, bd. 4, p. 291-372, 3 taf.

OLSSON, P.

1867. Entozoa, iakttagna hos Shandinaviska hafsfiskar. Platyelminthes. Lund's Universitets Arsskrift, $3: 1-59,2$ taf.

1876. Bidrag till Skandinaviens Helminthfauna. I. Kongliga Svenska Vetenskaps Akademiens nya Handlingar, bd. 14 , no. 1,35 p., 4 pl.

1893. Bidrag till Skandinaviens Helminthfauna. II. Ibid., bd. 25 , no. I 2,4 I P., 5 pl.

PRATT, H. S.

1902. Synopses of North American invertebrates. xir. The trematodes. Part II. The Aspidocotylea and the Malacocotylea, or Digenetic Forms. American Naturalist, vol. 36, p. $887-97$ I.

Rudol,pHr, C., A.

r809. Entozoorum, sive vermium intestinalium historia naturalis, vol. II, pt. I. Amstelædami.

1810. Entozoorum, sive vermium intestinalium historia naturalis, vol. II, pt. 2. Amstelædami.

1819. Entozoorum synopsis. Berolini.

RUTTER, C.

1902. Natural history of the quinnat salmon. A report of investigations in the Sacramento River 1896-1901. Bulletin U. S. Fish Commission, vol. xxir, p. 67-143.

SCHNEIDER, G.

1902. Ichthyologische Beiträge. In. Ueber die in den Fischen des Finnischen Meerbusens vorkommenden Endoparasiten. Acta Societatis pro Fatna et Flora Fennica, vol. 22, no. 2, P. 1 \&

STAFFORD, J.

1904. Trematodes from Canadian fishes. Zoologischer Anzeiger, bd. 27, p. $48_{1-495}$. 
STILES, C. W., and HASSAlL, A.

1894. A preliminary catalogue of the parasites contained in the collections of the United States Bureau of Animal Industry, United States Army Medical Museum, Biological Department of the University of Pennsylvania (Coll. Leidy) and in Coll. Stiles and Coll. Hassall. Veterinary Magazine, vol. I, p. 245-253, 413-437.

TosH, JAS, R.

1905. On the internal parasites of the Tweed salmon. Annals and Magazine of Natural History, 7 ser., vol. 16, p. II5-119, 1 pl.

ZSCHOKKE, FiR.

1899. Eirster Beitrag zur Parasitenfauna von Trutta salar. "Verhandlungen der Naturforschenden Gesellschaft in Basel, bd. 8, p. $76 \mathrm{I}-795$, pl. Ix.

I89o. Ueber Bothriocephalenlarven in Trutta salar. Centralblatt für Bakteriologie und Parasitenkunde, bd. 7, p. 393-396, 435-439, 5 fig.

1891. Die Parasitenfauna von Trutta salar. Ibid., bd. 10, p. 694-699, 738-745, 792-801, 829-838, $8 \mathrm{tab}$.

1896. Zur Faunistik der parasitischen Würmer von Süsswasserfischen. Ibid., bd. 19, p. $77^{2-784}$, $815-825$.

1902. Marine Schmarotzer in Süsswasserfischen. Verhandlungen der Naturforschenden Gesellschaft in Basel, bd. $16, p .118-157$.

\section{EXPLANATION OF PLATE.}

FIG. I. Azygia sebago. Group of individuals from Salmo sebago, after preservation in corrosive sublimate and then alcohol. $X_{2}$.

2. Azygia sebago. Specimen from salmon, stained and mounted in balsam. Dorsal view. $X_{1} 21 / 2$.

3. Azygia sebago. Anterior region of alimentary canal in lateral aspect. Reconstruction by Messrs. W. M. Anderson and H. B. Boyden. in, intestine; $a$, oesophagus; os, oral sucker; ph, pharynx. Highly magnified.

4. Azygia sebago, Longisection showing relations of principal organs. exc, main excretory vessels; lpm, longitudinal parenchym muscles, for explanation of which compare text; zil, follicles of vitellarium. Camera drawing. $\times 358$.

5. Azygia sebago. Female reproductive system in dorsal aspect. Semidiagrammatic to show relation of organs in ovarial complex. $/ c$, Laurer's canal; od, germ duct; ov, germarium; $s g$, shell gland; $u t$, first coils of uterus; $y d$, transverse vitelline duct; $y r$, yolk reservoir. After reconstruction by Messrs. Anderson and Boyden. Highly magnified.

6. Azygia scbago. Transsection through ovarial complex, showing relations of organs to common capsule (see text). in, intestinal crura; lpm, longitudinal parenchym muscles; ov; germ gland; $s g$, shell gland; $u t$, first coil of uterus; vit, follicle of vitellarium; $y d$, common yolk duct and part of yolk reservoir. Camera drawing $\times 60$.

7. Sparganum scbago, nov. sp. Bothriocephalid larva from spleen of Salmo sebago. Drawn from alcoholic specimen. $\times 2$.

8. Head of larva, shown in fig. $7 \times 25$.

9. Sparganum sebago, nov, sp. Bothriocephalid larva from body cavity of Salmo sebago. Urawn from alcoholic specimen. $\times 2$.

Io. Head of larva, shown in fig. 9. $\times 25$. 


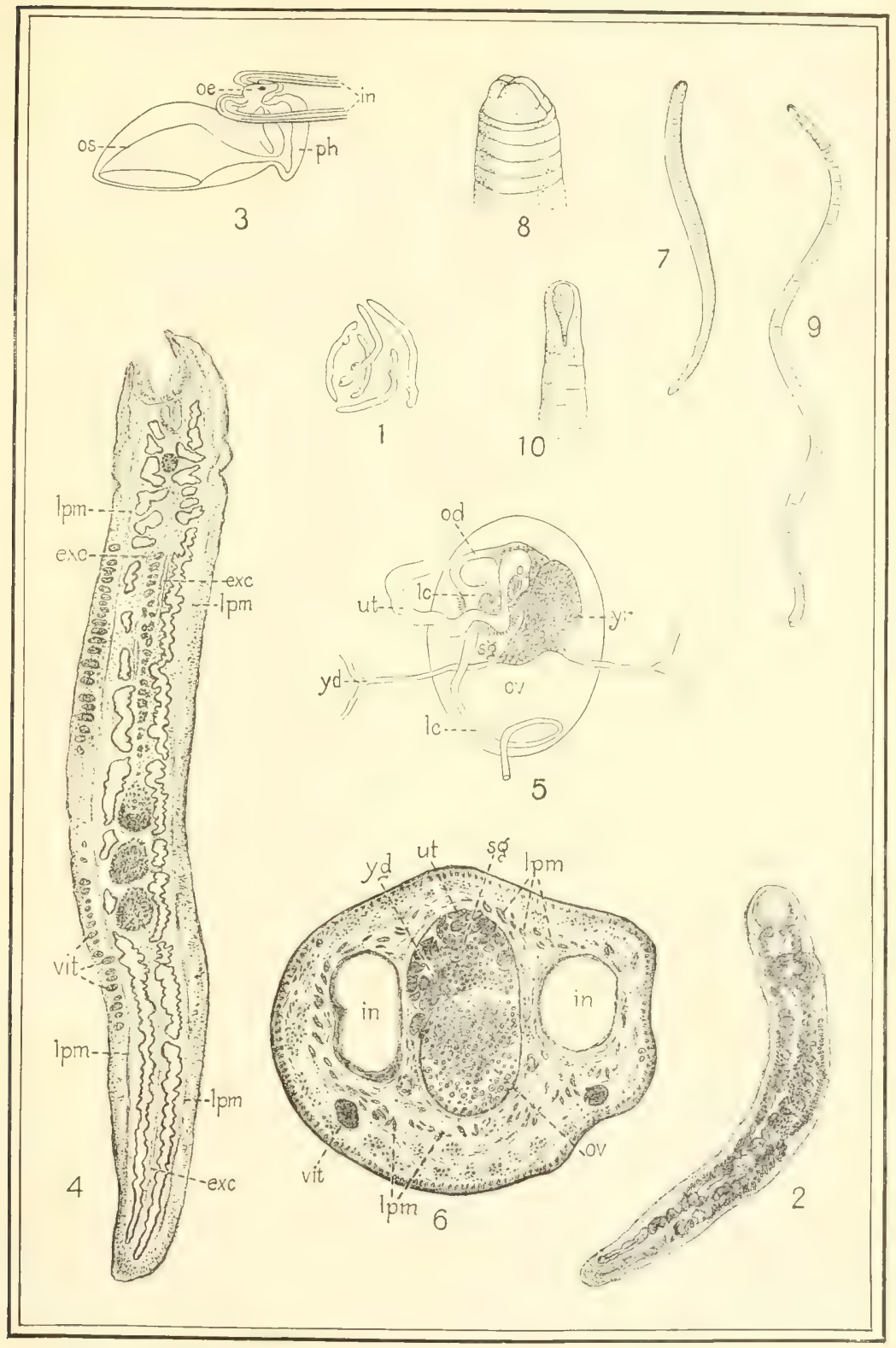








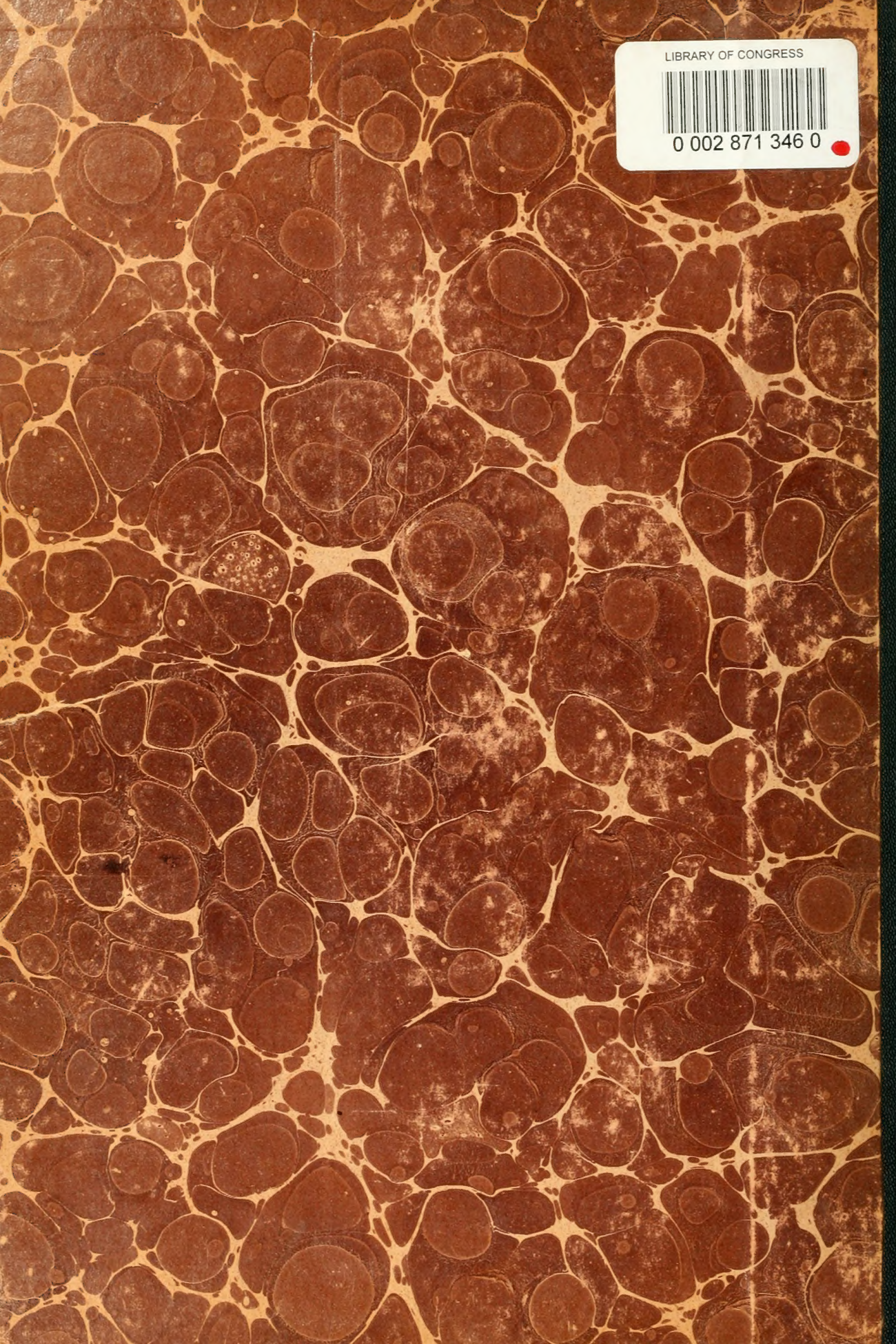

